\title{
Enrichment in critical metals (In-Ge) and Te-Se in epithermal deposits of the 'La Carolina' district, San Luis, Argentina
}

\author{
M. C. Gallard-Esquivel ${ }^{1}$, A. Cepedal ${ }^{2}$, M. Fuertes-Fuente ${ }^{2, *}$ and A. Martin-Izard ${ }^{2}$ \\ 1 Department of Geology, University National of San Luis-CONICET, San Luis, Argentina \\ 2 Department of Geology, University of Oviedo, Oviedo, Spain
}

[Received 13 January 2017; Accepted 23 December 2017; Associate Editor: Eimear Deady]

\section{ABSTRACT}

Epithermal Au-Ag deposits of the La Carolina district, in the San Luis metallogenetic belt (Argentina), are related spatially and genetically to Mio-Pliocene volcanism. In this district, mineralization in the Cerro Mogote and Puesto La Estancia prospects occur as disseminations, veins and fracture/cavity infillings in volcanic/ pyroclastic rocks, metamorphic basement and hydrothermal breccias. The gangue assemblage is dominated by carbonates (siderite, rhodochrosite, kutnahorite, dolomite). The main sulfides are pyrite, sphalerite, galena and chalcopyrite. Pyrite and sphalerite have compositional zoning, the former with As-rich cores and Cu-rich overgrowths, the latter with Fe-rich and Fe-poor bands. Sphalerite shows variable contents of Mn, Cu, In, Ga, $\mathrm{Ge}$ and Ag. The In-richest sphalerite hosts up to $5940 \mathrm{ppm}$ In but also contains elevated concentrations of $\mathrm{Cu}, \mathrm{Ag}, \mathrm{Ga}$ and $\mathrm{Ge}$, suggesting a coupled substitution mechanism resulting in enrichments in monovalent $\left(\mathrm{Ag}^{+}, \mathrm{Cu}^{+}\right)$and trivalent-tetravalent cations $\left(\mathrm{Ga}^{3+}, \mathrm{In}^{3+}, \mathrm{Ge}^{4+}\right)$. The main precious metal minerals are Ag-rich tetrahedrite, acanthite, argyrodite, pearceite-polybasite and Au-Ag alloy. Locally, Se and/or Te-enriched minerals include galena $\mathrm{Pb}\left(\mathrm{S}_{0.9-1} \mathrm{Se}_{0.1-0}\right)$, hessite $\mathrm{Ag}_{2}\left(\mathrm{Te}_{0.9-1} \mathrm{Se}_{0.1-0}\right)$, Se-rich cervelleite $\mathrm{Ag}_{4}\left(\mathrm{Te}_{1.3-0.9} \mathrm{~S}_{1-0.5}\right.$ $\left.\mathrm{Se}_{0.5-0.2}\right)$, and also alburnite $\left[\mathrm{Ag}_{8} \mathrm{GeTe}_{2} \mathrm{~S}_{4}\right]$ and benleonardite $\left[\mathrm{Ag}_{15} \mathrm{Cu}\left(\mathrm{As}, \mathrm{Sb}_{2} \mathrm{~S}_{7} \mathrm{Te}_{4}\right]\right.$. Pearceite contains Te (3.6-4.3 wt.\%) and Se (1-2.3 wt.\%) substituting for $\mathrm{S}$, which are unusually high concentrations for this mineral. The Puesto La Estancia deposit contains various tellurides including sylvanite, petzite, stutzite, altaite, tellurobismuthite and volynskite. This study shows that the chemistry of the fluids fluctuated during ore deposition suggesting different fluid pulses (system rejuvenation and/or boiling). The enrichment in Te, Se and $\mathrm{Bi}$ enrichment is supportive of a magmatic contribution to the ore fluid, while graphite in the metamorphic basement could be the source of germanium, although a magmatic source cannot be ruled out.

KEYWoRDs: argyrodite, alburnite, In-bearing sphalerite, pearceite-polybasite group, San Luis Metallogenic Belt.

\section{Introduction}

Demand has increased significantly for ores containing elements such as Te, Ge, Se and In. This is due to the fact that these elements are critical for a variety of high-technology applications, and future demand for them will continue to increase (Paradis,

*E-mail: mercedf@geol.uniovi.es https://doi.org/10.1180/minmag.2017.081.105
2015). In addition, In and Ge are included in the latest list of Critical Raw Materials 2017 released by the European Commission. These elements seldom form primary ores but are mainly obtained as by-products of the refining of major metals from base-metal ores (Graedel et al., 2014; Paradis, 2015). For instance, Te and Se are largely produced from copper refining, and In and Ge from the processing of sphalerite in base metal ores. In order for the worldwide reserves/resources to be able to meet the ever-growing demand, alternative sources

This paper is part of a special issue entitled 'Critical-metal mineralogy and ore genesis'. The Applied Mineralogy Group of the Mineralogical Society and the IMA Commission on Ore Mineralogy have contributed to the costs of Open Access publication for this paper. 
for these raw materials are essential. These four elements mentioned above occur in different ore types, including porphyry-epithermal deposits (Höll et al., 2007; Graedel et al., 2014; Paradis, 2015).

The Pampean Flat-Slab $27^{\circ} 00^{\prime}-33^{\circ} 30^{\prime}$ segment in the central Andes of Argentina records a Miocene-Pliocene magmatic episode related to the eastward migration of the Andean magmatic arc (Ramos et al., 2002). This migration was due to the flattening of the Nazca plate after the collision of the Juan Fernández Bridge, in this plate, with the Chilean trench (Barazangi and Isacks, 1976; Jordan et al., 1983; Jordan and Allmendinger, 1986; Gutscher et al., 2000). From a metallogenetic point of view, the Pampean Flat-Slab segment is economically important as it hosts several porphyry and epithermal deposits, some of them world-class. From north to south, the three main metallogenic districts are Farallón Negro, Nevados de Famatina and San Luis Metallogenic Belt. The Farallón Negro district hosts two world-class porphyry deposits, Bajo de la Alumbrera (e.g. Proffett, 2004) and Agua Rica (e.g. Landtwing et al., 2002; Franchini et al., 2011, 2015). Apart from the aforementioned deposits, this district hosts several epithermal systems, such as Alto de la Blenda and Capillitas, (e.g. Márquez-Zavalía, 1999; Márquez-Zavalía and Heinrich, 2016). The Nevados de Famatina district includes the $\mathrm{Cu}-\mathrm{Mo}-\mathrm{Au}$ porphyry-high-sulfidation epithermal system (Nevados de Famatina) and other epithermal deposits (e.g. Losada-Calderón and McPhail, 1996). The San Luis Metallogenic Belt (Urbina and Sruoga, 2009) hosts silver-gold epithermal and gold-copper porphyry deposits. The two most important districts in the belt are $\mathrm{La}$ Carolina and Cañada Honda (Urbina et al., 1997; Urbina, 2005a, $b$; Urbina and Sruoga, 2009; GallardEsquivel et al., 2012, 2015). In some of the epithermal deposits mentioned above parageneses are found with Ge-, Te-, Se- and In-bearing minerals such as Alto de la Blenda (Márquez-Zavalía and Heinrich, 2016) and Capillitas (Marquez-Zavalía and Craig, 2004) where new mineral species containing these elements (i.e. putzite, catamarcaite and ishiharaite) were identified (Paar et al., 2004a; Putz et al., 2006; Márquez-Zavalía et al., 2014). In the same way, the Cerro Negro in the Nevados de Famatina district presents a Te-bearing paragenesis (Schalamuk and Logan, 1994). The Cerro CachoSierra de Umango (de Brodtkorb, 2009) is the type locality of two copper selenides: umangite and klockmannite (Paar et al., 2004b).

The 'La Carolina' district is a volcanic complex of $\sim 9 \mathrm{~km}^{2}$ that comprises several small mineralized areas (Urbina et al., 1997), including Cerro Mogote and Puesto La Estancia prospects on which this study is focused. The district has been explored intermittently for gold since the 1980s until the first decade of the present century, when the exploration was stopped. However, the district has not been explored for other commodities such as In and Ge. The aim of the present study was to characterize the mineralogy and paragenesis of the Te-Ge-Se-Inbearing minerals that occur in the epithermal mineralizations of the Cerro Mogote and Puesto La Estancia prospects. Here the results of combined optical microscopy, scanning electron microscopy (SEM) and electron microprobe analysis (EMPA) for several ore-bearing samples are presented. The results provide a better understanding of the distribution of these elements in porphyry-epithermal systems in the central Andes of Argentina.

\section{Geological setting}

The La Carolina district is located in the southern sector of the Sierras Pampeanas Orientales geological province (Caminos, 1979), in the Sierra de San Luis (San Luis province, Argentina) (Fig. 1). It is located at the western end $\left(32^{\circ} 48^{\prime} 10^{\prime \prime} \mathrm{S}, 66^{\circ} 3^{\prime} 45^{\prime \prime}\right.$ W, 1750 m.a.s.l) of the San Luis metallogenetic belt, which is related spatially and genetically to Miocene-Pliocene volcanism.

These volcanic rocks intruded and overlaid a Proterozoic-Palaeozoic basement, which comprises rocks of different metamorphic grades, and igneous rocks corresponding to different cycles of granitic plutonism in the Palaeozoic (Morosini et al., 2017). Intrusive magmatism is part of the Famatinian orogenic cycle, which extended from early Precambrian to Devonian time (Aceñolaza and Toselli, 1981). In the study area, the metamorphic basement comprises the high-grade Pringles Complex (Sims et al., 1997) and the low-grade San Luis Formation (Prozzi and Ramos, 1988; Prozzi, 1990). The former includes schists, gneisses, migmatites and amphibolites, and the latter phyllites, meta-quartzites and meta-volcanic rocks. The contacts between these metamorphic units consist of $\mathrm{N}$ to NNE-trending ductile shear zones. In addition, these rocks show a sub-vertical penetrative NNE foliation, which is attributed to compression of the rocks during the Famatinian orogeny (Ortiz Suárez et al., 1992; Sato et al., 2003).

Reactivation of existing N-S, E-W and NW-SE oriented faults during the Andean orogenic cycle gave the Sierras Pampeanas of San Luis a fault- 
a

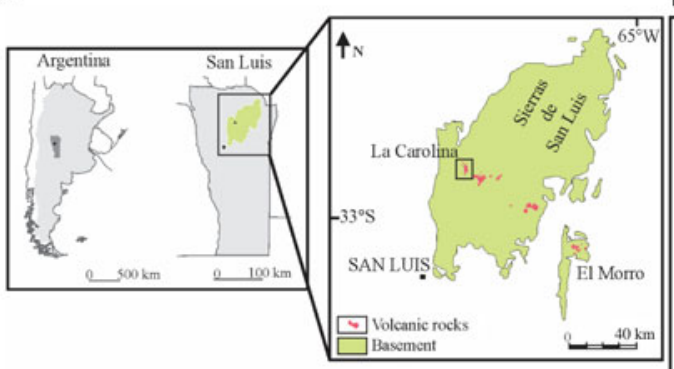

b

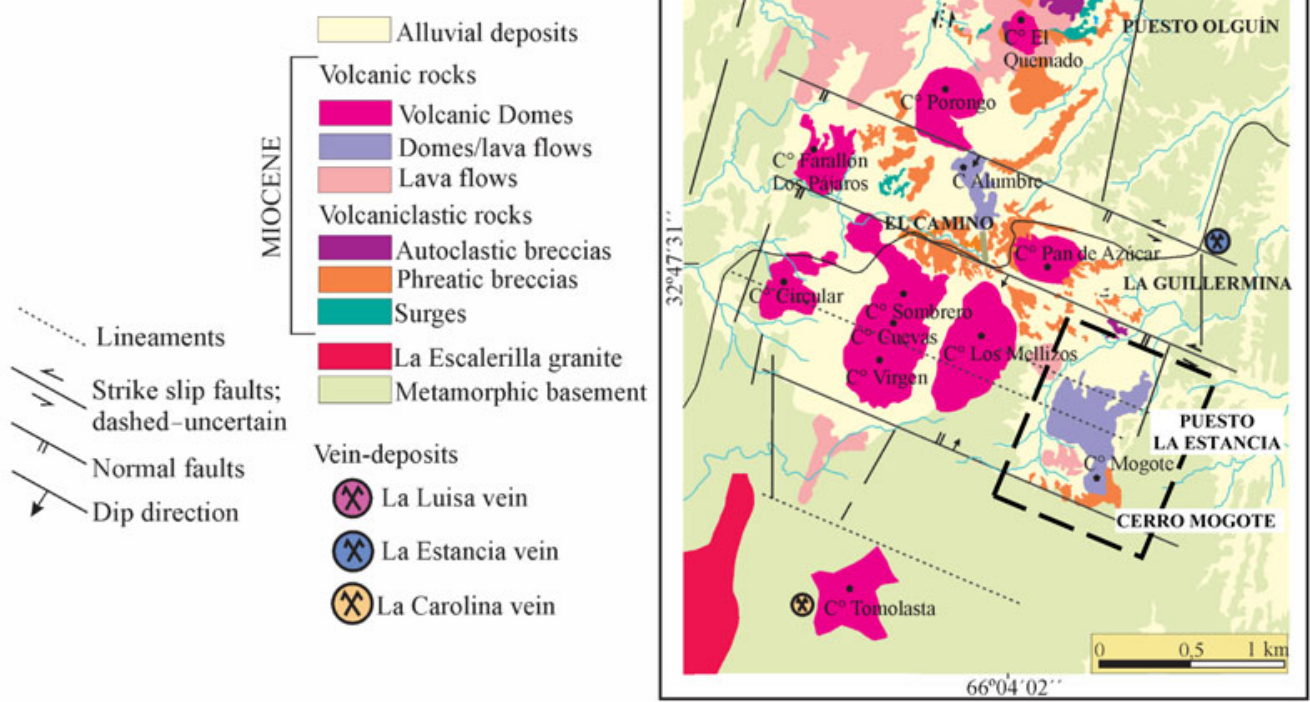

Fig. 1. (a) Location of the La Carolina district at the western end of the metallogenic belt of San Luis, in San Luis province, Argentina. (b) Geological map of the La Carolina district, showing various prospects and major vein deposits. The study area is marked by a dashed-line rectangle (after Gallard-Esquivel, 2015).

block style of deformation with a steep western hillslope where the uplifted Andean front is located. This structural pattern controlled the MiocenePliocene magma emplacement. In La Carolina district, structural analyses show that the early structures strongly controlled the emplacement of the volcanic rocks and associated hydrothermal mineralization (Japas et al., 2011a,b; GallardEsquivel et al., 2012). This volcanic district is rhomboid in shape, and characterized by two parallel-to-foliation sets of faults $(\mathrm{N}-\mathrm{S}$ and $\mathrm{NNE}$, Fig. 1). Slip on the main $\mathrm{N}-\mathrm{S}$ faults indicates dominant right-lateral motion whereas NNE faults show components of vertical slip. The presence of a gentle deflection in the foliation trend $\left(\sim 30^{\circ}\right)$ resulted in a NNE releasing bend, allowing magma emplacement in this pull-apart structure. Furthermore, previous studies by Japas et al. (2010) at Cañada Honda district confirm strike-slip structures controlling Miocene-Pliocene volcanic emplacement at the western end of the San Luis metallogenetic belt (Japas et al., 2011a). In the La Carolina district, volcanic activity occurred between 8.2 and 6.3 Ma (Urbina and Sruoga, 2009) and consists of lavas and pyroclastics (surges and phreatic breccias) of andesitic, dacitic, latitic and trachytic composition. The magmas of intermediate composition belong to normal to high$\mathrm{K}$ calc-alkaline and shoshonitic suites (GallardEsquivel et al., 2015). The La Carolina volcanic field has been interpreted as a maar-diatreme system, which was disturbed by dome emplacement (Sruoga et al., 1996). Spatially related to this maardiatreme system there are several small $\mathrm{Au}-\mathrm{Ag}$ epithermal deposits (Urbina et al., 1997; Urbina and Sruoga, 2009). The ore occurrences show two 
main styles: (1) disseminations including stockworks, disseminated zones and veins/veinlets in volcanic and pyroclastic rocks, in the metamorphic basement, or in hydrothermal breccias; and (2) major veins hosted by the igneous-metamorphic basement (Márquez-Zavalía and Galliski, 1994, 2004; Urbina et al., 1997; Urbina, 2005a,b; Urbina and Sruoga, 2009; Gallard-Esquivel et al., 2012).

\section{Sampling and analytical procedures}

Polished-thin and polished sections of 47 samples were taken from three drill cores of Cerro Mogote prospect (DDH51, DDH36 and DDH49) and two drill cores from the Puesto La Estancia prospect
(DDH31 and DDH33, Fig. 2a). These samples were studied by transmitted- and/or reflected-light microscopy, and using a JEOL-6610LV scanning electron microscope in association with chemical microanalysis by means of energy dispersive X-ray (EDAX). Electron microprobe analyses (EMPA) were performed using a CAMECA SX100 equipped with five wavelength-dispersive spectrometers. Major elements were determined at $20 \mathrm{kV}$ accelerating potential, $20 \mathrm{nA}$ beam current and an acquisition time between 10 and $20 \mathrm{~s}$ on X-ray peak and half that time on the background. The standard deviation of the EMPA is $<0.1 \%$. In order to analyse the trace-element content of sulfides, these analytical conditions were modified in order to attain lower detection limits. In the case of pyrite,



FIG. 2. (a) Geological map of the Puesto La Estancia and Cerro Mogote prospects, showing the locations of the drill cores from which samples were taken. (b) Sample from drill core DDH51 (92 m depth) corresponding to fractured and mineralized metamorphic host-rocks. (c) Photomicrograph under plain-polarized and transmitted light of a thin section from the sample in $(b)$. The photo shows a vein filled with quartz (qz), pyrite (py) and illite (ilt), the latter which appears as pseudomorphs after adularia crystals. (d) Phreatic breccia from drill core DDH31 (79.5 m depth). 
the operating conditions were $20 \mathrm{kV}, 100 \mathrm{nA}$ and $120-180 \mathrm{~s}$ count time. The detection limits were $250 \mathrm{ppm}$ for $\mathrm{Au}, 245 \mathrm{ppm}$ for $\mathrm{Ag}, 205 \mathrm{ppm}$ for $\mathrm{Sb}$, $160 \mathrm{ppm}$ for $\mathrm{Cu}, 88 \mathrm{ppm}$ for Se, $200 \mathrm{ppm}$ for Te, $280 \mathrm{ppm}$ for As, $200 \mathrm{ppm}$ for $\mathrm{Zn}, 150 \mathrm{ppm}$ for $\mathrm{Ni}$, and $495 \mathrm{ppm}$ for Co (95\% confidence). X-ray mapping with EMPA identified zonings of trace elements (e.g. $\mathrm{Cu}, \mathrm{Se}, \mathrm{Ag}$ ) that are not detectable by SEM-EDAX. The conditions for the X-ray mapping were $20 \mathrm{kV}$ accelerating potential, $100 \mathrm{nA}$ beam current, $2 \mu \mathrm{m}$ scan distance, and $100 \mathrm{~ms}$ X-ray peak acquisition time per point.

Operating conditions for sphalerite analyses were $20 \mathrm{kV}$ and $20 \mathrm{nA}$ for most elements, and $100 \mathrm{nA}$ for In and Ag. The detection limits for trace elements measured in sphalerite (i.e. In, $\mathrm{Ga}, \mathrm{Cd}$, $\mathrm{Ag}, \mathrm{Ge}$ ) were $135 \mathrm{ppm}$ for $\mathrm{In}, 114 \mathrm{ppm}$ for $\mathrm{Ga}$, $120 \mathrm{ppm}$ for $\mathrm{Ge}, 526 \mathrm{ppm}$ for $\mathrm{Cu}, 110 \mathrm{ppm}$ for $\mathrm{Ag}$ and $646 \mathrm{ppm}$ for $\mathrm{Cd}(95 \%$ confidence $)$. The detection limits for trace elements measured in galena were $191 \mathrm{ppm}$ for In, $150 \mathrm{ppm}$ for $\mathrm{Ge}$, $140 \mathrm{ppm}$ for $\mathrm{Ag}, 350 \mathrm{ppm}$ for $\mathrm{Sb}, 1600 \mathrm{ppm}$ for $\mathrm{Bi}$, $1050 \mathrm{ppm}$ for $\mathrm{Se}, 525 \mathrm{ppm}$ for $\mathrm{Cu}$ and $750 \mathrm{ppm}$ for $\mathrm{Zn}$ (95\% confidence).

The X-ray intensities acquired were corrected for atomic number, mass absorption and secondary fluorescence effects using the CAMECA x-phi program. The following X-ray lines and analyzing crystals (in parentheses), were used: $A u L \alpha$ (LLiF), $\mathrm{Ag} L \alpha$ (LPET), $\mathrm{Bi} L \alpha$ (LLiF), $\mathrm{Sb} L \alpha$ (LPET), $\mathrm{Pb} M \alpha$ (LPET), $\mathrm{Fe} K \alpha$ (LLiF), $\mathrm{CuK} \alpha$ (LLiF), $\mathrm{ZnK} \alpha$ (LLiF),

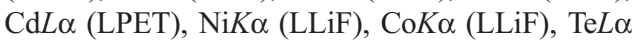
(LPET), SK $\alpha$ (LPET), Se $L \alpha$ (LTAP), As $L \beta$ (LTAP), $\operatorname{In} L \alpha$ (LPET), GaK $\alpha(\mathrm{LLiF})$. The potential X-ray emission lines interferences were taken into account (i.e. As-on-Se, Te and Se-on- $\mathrm{Pb}$, and Inon-Sn and Ga) and the Virtual WDS software (Reed and Buckley, 1996) was used for developing the analysis strategy. The well documented Sn-on-In interference ( $\mathrm{Sn} L \eta$ line-on- $\operatorname{In} L \alpha$ line) was ruled out as the $\mathrm{Sn}$ content of the sphalerite studied is negligible. Regarding As-on-Se peak overlap, the intensity of this interference was corrected using the 'overlapping option' provided by the CAMECA SX Peak Sight Software. Moreover, the background position was set much closer to the $\operatorname{Se} L \alpha$ peak position and was estimated by counting at each side of the peak. To avoid In-on-Ga peak overlap, the selected X-ray lines $\operatorname{In} L \alpha$ and $\mathrm{GaK} \alpha$ were analysed using LPET and LLiF crystals, respectively. To avoid $\mathrm{Se}-\mathrm{on}-\mathrm{Pb}$ peak overlap, the chosen $\mathrm{X}$-ray lines were $\mathrm{Se} L \alpha$ (LTAP) and $\mathrm{Pb} M \alpha$ (LPET). For Teon- $\mathrm{Pb}$, the selected line was $\mathrm{Te} L \alpha$ because it overlaps third- and fourth-order emission lines of
$\mathrm{Pb}$ which, essentially, are not excited under the current analytical conditions $(20 \mathrm{kV}, 100 \mathrm{nA})$. Thus, the influence of this overlap is considered to have been negligible. The standards employed were commercially available metals, sulfides, selenides and tellurides: $\mathrm{FeS}_{2}, \mathrm{Ag}_{2} \mathrm{Te}, \mathrm{Au}, \mathrm{Sb}_{2} \mathrm{~S}_{3}$, $\mathrm{PbS}, \mathrm{Bi}, \mathrm{InAs}, \mathrm{CoAsS}, \mathrm{Ni}, \mathrm{CuFeS}_{2}, \mathrm{ZnS}, \mathrm{Bi}_{2} \mathrm{~S}_{3}$, $\mathrm{FeAsS}, \mathrm{Cu}$, and $\mathrm{CdSe}$. All analyses were obtained at the University of Oviedo, Spain.

\section{Sample description and results}

Sulfide mineralization occurs as disseminations to vein/veinlets and fracture infillings in both the volcanic rocks and the metamorphic basement. In the latter, graphite was observed locally in the veins and in their selvages. Moreover, the ore mineralization is also found in hydrothermal breccias, mainly as cavity infilling. Sulfide mineralization mainly consists of pyrite with smaller amounts of sphalerite and galena. Chalcopyrite and pyrrhotite occur in minor amounts and commonly as inclusions in pyrite and partially replaced by marcasite, tetrahedritetennantite, digenite, covellite and acanthite.

Two types of veins/veinlets and fracture infillings (Fig. $2 b$ ) have been defined on the basis of the gangue minerals that accompany the sulfides: Type1 or quartz + sericite + illite + sulfide veins and Type- 2 or quartz + carbonate + sulfide veins.

In Type-1 veins, which occur mainly in drill cores DDH51 and DDH36 from the Cerro Mogote prospect (Fig. 2a), pyrite is the dominant sulfide followed by sphalerite and galena in lesser proportions. Both quartz and pyrite are located at the vein margins, although they are sometimes the only infill. Quartz grains are heterogeneous in terms of size and show no preferential growth orientation (Fig. 2c). This type of vein generally shows grains, tabular in shape, pseudomorphed by sericite-illite which may have replaced pre-existing adularia as it has the characteristic habit of the low-temperature $\mathrm{K}$-feldspar. The last infill is also illite.

Type-2 veins are characterized by the presence of abundant carbonates, which exhibit different textures and compositions: fine-grained $\mathrm{Fe}-\mathrm{Mn}$ carbonates (siderite-rhodochrosite), bladed rhodochrosite and kutnahorite, or banded crystals with very variable amounts of $\mathrm{Mn}-\mathrm{Mg}-\mathrm{Fe}-( \pm \mathrm{Ca})$. The $\mathrm{Ca}$ content of carbonates increases with depth and time in the paragenetic sequence. Kutnahorite and dolomite represent the carbonates with the highest $\mathrm{Ca}$ contents, calcite not having been detected. Quartz and $\mathrm{K}$-feldspar are less common, the latter occurring 
as tabular crystals in vein selvages and partially replaced by carbonates. In addition, diamond-shaped adularia is intergrown with carbonate crystals. Sphalerite and galena are more abundant in these veins than in the Type-1 veins. Type- 2 veins are prevalent in the Puesto La Estancia prospect (drill cores DDH31 and DDH33, Fig. $2 a$ ), below $\sim 110 \mathrm{~m}$ from the present erosion level, crosscutting volcanic rocks of latite-andesitic composition.

Metallic mineralization is also found in hydrothermal breccias (Fig. $2 d$ ), mainly in the shallowest parts of the Puesto La Estancia prospect (from $\sim 110 \mathrm{~m}$ below the present erosion level). The hydrothermal breccias are matrix-supported (60-70\% matrix), and consist of subangular to surrounded polymict clasts set in a matrix that varies from rock flour to hydrothermal massive cement (carbonate + quartz + sulfide), commonly containing vugs. The clasts are mainly fragments of volcanic rocks of latite-andesitic composition. These fragments show hydrothermal alteration that varies from phyllic to argillic alteration and/or carbonatization. Smaller numbers of clasts of mica-schist from the metamorphic basement also occur. In these breccias, the sulfides are accompanied by carbonates with compositions similar to those that infill interclast cavities. The sulfides are present either as thin crusts on the cavity walls or as semimassive to massive filling.

\section{Sulfide textures and chemical composition}

\section{Pyrite}

Pyrite is ubiquitous and commonly occurs as subhedral to cubic grains $(4 \mu \mathrm{m}$ to $\sim 1 \mathrm{~mm}$ in size), disseminated throughout the matrix of hostrocks (volcanic and metamorphic), of the breccias and within the breccia clasts. Pyrite was the first sulfide deposited although it does occur intermittently throughout the period of sulfide-carbonate deposition. Pyrite crystals exhibit several concentric overgrowth zones, some of them inclusion-rich, implying multiple episodes of deposition (Fig. 3). The inclusions consist of $\mu \mathrm{m}$ to sub- $\mu \mathrm{m}$ grains of galena, Ag-rich tetrahedrite, pearceite and acanthite. Where these inclusions were plucked during polishing, pyrite shows a pseudoporous texture. The last stage of pyrite deposition is characterized by small crystals $(<50 \mu \mathrm{m})$ associated with bladed Mn-rich carbonate and alabandite, which grew at the grain margins of sphalerite in hydrothermal breccias (Fig. 4a,b).

Back-scattered electron images, X-ray mapping and EMPA of pyrite crystals from sample DDH51-
106.4 reveal that cores are rimmed by at least three generations of pyrite bands (Fig. $3 b-f$ ). The results of representative EMPA, carried out on each pyrite generation, are listed in Table 1. The cores of these crystals are characterized by a high variation in As content. This variation is oscillatory (Fig. $3 b, c$ ) and there is also a differential enrichment of As in growth sectors, similar to that observed by Chouinard et al. (2005). Based on the EMPA, As values range from 0.2 to $5 \mathrm{wt} . \%$. The pyrite cores also show trace quantities of $\mathrm{Cu}$ (up to $1697 \mathrm{ppm}$ ), $\mathrm{Ag}$ (up to $643 \mathrm{ppm}$ ) and $\mathrm{Te}$ (up to $595 \mathrm{ppm}$ ), whereas $\mathrm{Sb}, \mathrm{Au}, \mathrm{Ni}$ and $\mathrm{Co}$ were below the limits of detection (LOD). The cores are rimmed by a growth band with few or no detectable trace elements (barren pyrite), followed by a $\mathrm{Cu}$-rich band (up to $6209 \mathrm{ppm} \mathrm{Cu}$ ). The last stage of pyrite growth is also poor in trace elements. The X-ray maps for Se (Fig. $3 f$ ) indicate that this element is mainly concentrated in the As-rich cores.

Electron microprobe analyses and the X-ray maps show that the main substitution is As for $\mathrm{S}$ in pyrite (Cook and Chryssoulis, 1990; Simon et al., 1999; Savage et al., 2000); however, a correlation between As and Fe also exists (Fig. 3b,d). The As-rich cores are also Ag-bearing, suggesting that both ions entered the structure of pyrite as part of a coupled substitution. Chouinard et al. (2005) suggested a possible substitution of $\mathrm{Ag}^{+}+\mathrm{As}^{3+}=2 \mathrm{Fe}^{2+}$.

\section{Galena}

Galena typically occurs as inclusions in, and intergrown with, early pyrite and/or sphalerite (Fig. 4b). In places, it overgrew pyrite (Fig. $3 a$ ). Electron microprobe analyses show that $\mathrm{Ag}, \mathrm{Bi}, \mathrm{Se}$ and, to a lesser extent, $\mathrm{Sb}$ are the most common trace elements. The largest amounts of $\mathrm{Ag}$ and $\mathrm{Bi}$ (up to 5056 and $9188 \mathrm{ppm}$, respectively) were measured in galena from core samples located at $\sim 200 \mathrm{~m}$ below the present surface. In this case, the correlation observed between these elements indicates a coupled substitution of $\mathrm{Pb}^{2+}$ for $\mathrm{Bi}^{3+}$ and $\mathrm{Ag}^{+}$.

\section{Sphalerite}

In hydrothermal breccias, sphalerite commonly exhibits compositional growth banding, sometimes oscillatory, from dark red Fe-rich bands to lighter orange-yellow Fe-poor sphalerite (Fig. 4a). However, this banded sphalerite is uncommon in the veins. Sphalerite can show a black rim rich in Mn where it is in contact with Mn-rich carbonate (Fig. 4a,c). Disseminated chalcopyrite blebs are common and locally abundant (so-called 'chalcopyrite disease'). 



FIG. 3. (a) Photomicrograph of zoned pyrite crystals from sample DDH51-106.4, under plane-polarized and reflected light. EMPA X-ray images of As $(b), \mathrm{S}(c), \mathrm{Fe}(d), \mathrm{Cu}(e)$ and $\mathrm{Se}(f)$ showing the distribution of these elements in the zoned pyrite crystal. The core is As-rich with oscillatory and sector zoning, in antithetic relationship with $\mathrm{S}$ and Fe. The $\mathrm{Se}$ is concentrated in the As-rich zones. The red areas in part $(f)$ are Se-bearing galena grains. The core is overgrown by barren pyrite followed by a Cu-rich pyrite. The analytical conditions are indicated in the text.

In banded sphalerite, the blebs are abundant in the dark red Fe-rich bands, where coarser grains of chalcopyrite also occur with pyrrhotite (Fig. $4 b$ ).
The Fe content of sphalerite ranges between 0.1 and $12 \mathrm{wt} . \%$, although most of the sphalerite analyses show an Fe content of $<2$ wt.\% (Table 2, 

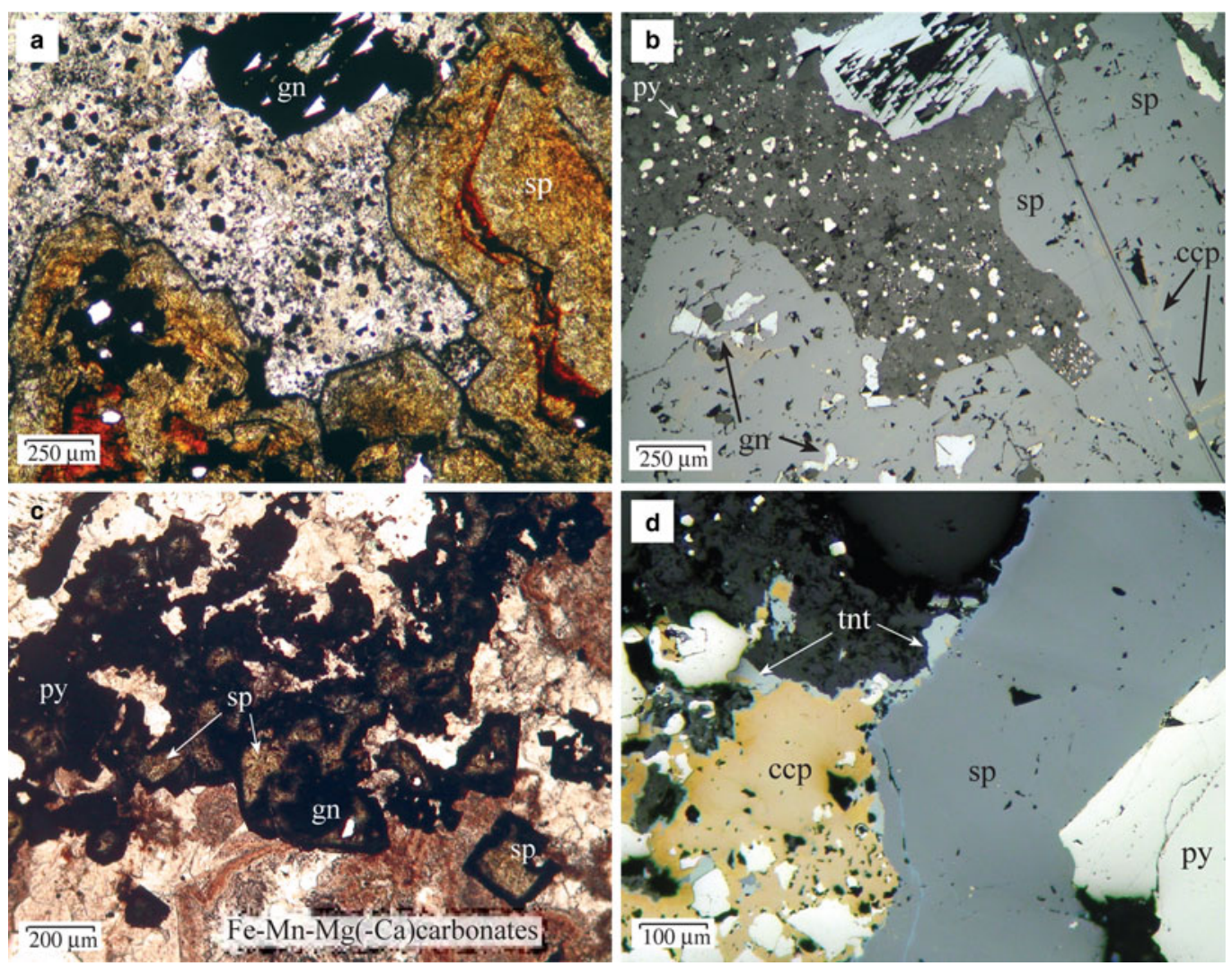

FIG. 4. (a) Photomicrograph of zoned sphalerite crystals infilling a breccia cavity from sample DDH31-79.5B, under plane-polarized and transmitted light. The red bands are rich in Fe (up to $12 \mathrm{wt} . \%$ ), and the largest amounts of In are found in the clear and yellowish Fe-poor sphalerite. Mn-carbonate is filling the interstitial cavities, with inclusions of pyrite and alabandite. The sphalerite crystals show a Mn-rich black rim at the contact with the carbonate. $(b)$ The same image under reflected light. The dark-red bands have abundant inclusions of chalcopyrite ('chalcopyrite disease') and sometimes pyrrhotite (not shown). (c) Photomicrograph of a quartz-carbonate-sulfide vein from sample DDH31-197, under plane-polarized and transmitted light. The sphalerite crystals show light brown cores, In-bearing, and black rims rich in Mn. There are two stages of carbonate filling, the first one, Fe-rich (red colour) and the second, Mn-rich, the latter partially replacing sphalerite crystals. $(d)$ Photomicrograph under plane-polarized and reflected light of a tennantitebearing mineralization (sample DDH51-76.5).

Fig. 5a). The highest values of Fe were measured in the dark-red bands of the zoned sphalerite crystals from hydrothermal breccias (Fig. 4a). The concentration of $\mathrm{Mn}$ is also highly variable, showing two different correlation trends between $\mathrm{Fe}$ and $\mathrm{Mn}$ (Fig. 5a): Fe-poor sphalerite from Cerro Mogote samples have, in general, a greater Mn content than sphalerite from the Puesto La Estancia prospect. In the latter, the lower Mn content of sphalerite is coincident with a significant abundance of $\mathrm{Mn}$-rich carbonates in the gangue minerals. Thus, the explanation for this sphalerite poorer in Mn could be that the carbonates tend to incorporate manganese easier than the sphalerite. Only the black rim developed between sphalerite and carbonates (Fig. 4a,c) appears enriched in Mn. In the case of $\mathrm{Cu}$, the majority of the analyses show $\mathrm{Cu}$ contents of $<2 \mathrm{wt} . \%$, although values up to $9 \mathrm{wt} . \%$ have been measured in sphalerite with chalcopyrite inclusions (chalcopyrite disease). These high values are due to submicrometre chalcopyrite inclusions having been analysed, and these analyses have not been considered. Nevertheless, $\mathrm{Cu}$ concentrations of tens of thousands of ppm (up to 3.6 wt.\%) were measured using a LA-ICP-MS by Cook et al. (2009) in samples from In-rich sphalerite 
TABLE 1. Selected electron microprobe analyses (wt.\%) of the different growth zones of pyrite from sample DDH51-106.4 (Fig. 3) in the Cerro Mogote prospect. Other elements analysed were $\mathrm{Au}, \mathrm{Sb}, \mathrm{Ni}$ and $\mathrm{Co}$, all of which were always below their detection limits.

\begin{tabular}{|c|c|c|c|c|c|c|c|c|c|}
\hline \multirow[b]{2}{*}{ wt. $\%$} & \multicolumn{3}{|c|}{ As-rich cores } & \multicolumn{3}{|c|}{ Barren-py } & \multicolumn{3}{|c|}{$\mathrm{Cu}$-rich } \\
\hline & & & & & & & & & \\
\hline S & 51.22 & 51.85 & 50.11 & 52.95 & 53.34 & 53.23 & 52.73 & 52.67 & 53.33 \\
\hline $\mathrm{Fe}$ & 45.54 & 45.94 & 44.81 & 46.76 & 46.65 & 46.58 & 46.24 & 45.45 & 46.56 \\
\hline $\mathrm{Cu}$ & 0.02 & - & 0.13 & - & 0.08 & 0.08 & 0.57 & 0.56 & 0.40 \\
\hline $\mathrm{Zn}$ & - & - & - & 0.03 & - & - & - & - & - \\
\hline As & 3.13 & 1.86 & 4.14 & 0.17 & - & - & 0.33 & 0.42 & 0.09 \\
\hline $\mathrm{Se}$ & 0.01 & 0.02 & - & - & - & - & - & - & 0.01 \\
\hline $\mathrm{Ag}$ & 0.04 & 0.03 & 0.03 & - & - & - & - & - & - \\
\hline $\mathrm{Te}$ & - & 0.03 & - & - & - & - & - & - & - \\
\hline Total & 99.96 & 99.76 & 99.23 & 99.96 & 100.19 & 99.97 & 99.93 & 99.19 & 100.43 \\
\hline \multicolumn{10}{|l|}{ at. $\%$} \\
\hline $\mathrm{S}$ & 65.06 & 65.59 & 64.50 & 66.28 & 66.54 & 66.53 & 66.16 & 66.48 & 66.41 \\
\hline $\mathrm{Fe}$ & 33.21 & 33.37 & 33.12 & 33.60 & 33.41 & 33.42 & 33.31 & 32.94 & 33.29 \\
\hline $\mathrm{Cu}$ & 0.01 & & 0.08 & & 0.05 & 0.05 & 0.36 & 0.36 & 0.25 \\
\hline $\mathrm{Zn}$ & & & & 0.02 & & & & & \\
\hline As & 1.70 & 1.01 & 2.28 & 0.09 & & & 0.18 & 0.23 & 0.05 \\
\hline $\mathrm{Se}$ & 0.01 & 0.01 & & & & & & & 0.01 \\
\hline $\mathrm{Ag}$ & 0.01 & 0.01 & 0.01 & & & & & & \\
\hline $\mathrm{Te}$ & & 0.01 & & & & & & & \\
\hline
\end{tabular}

-: below detection limit. 
TABLE 2. Average EMPA results of sphalerite from samples of drill cores from the Puesto La Estancia (DDH31, DDH33) and Cerro Mogote (DDH51, DDH36) prospects, La Carolina district.

\begin{tabular}{|c|c|c|c|c|c|c|c|c|c|c|c|c|c|c|c|c|c|c|c|c|}
\hline \multirow[b]{3}{*}{$\begin{array}{l}\text { wt. } \\
\%\end{array}$} & \multicolumn{8}{|c|}{ Cerro Mogote } & \multicolumn{12}{|c|}{ Puesto La Estancia } \\
\hline & \multicolumn{2}{|c|}{$\begin{array}{c}\text { DDH51- } \\
76.5\end{array}$} & \multicolumn{2}{|c|}{ DDH51-36 } & \multicolumn{2}{|c|}{$\begin{array}{c}\text { DDH51- } \\
100\end{array}$} & \multicolumn{2}{|c|}{$\begin{array}{c}\text { DDH36- } \\
191\end{array}$} & \multicolumn{2}{|c|}{$\begin{array}{c}\text { DDH33- } \\
203\end{array}$} & \multicolumn{2}{|c|}{$\begin{array}{c}\text { DDH33- } \\
208\end{array}$} & \multicolumn{2}{|c|}{$\begin{array}{c}\text { DDH33- } \\
245\end{array}$} & \multicolumn{2}{|c|}{$\begin{array}{c}\text { DDH31- } \\
79.5 \mathrm{~B}\end{array}$} & \multicolumn{2}{|c|}{$\begin{array}{c}\text { DDH31- } \\
79.5 \mathrm{G}\end{array}$} & \multicolumn{2}{|c|}{$\begin{array}{c}\text { DDH31- } \\
197\end{array}$} \\
\hline & $\begin{array}{l}\text { Avg. } \\
\text { (11) }\end{array}$ & $\mathrm{SD}$ & $\begin{array}{l}\text { Avg. } \\
(23)\end{array}$ & $\mathrm{SD}$ & $\begin{array}{l}\text { Avg. } \\
\text { (11) }\end{array}$ & $\mathrm{SD}$ & $\begin{array}{l}\text { Avg. } \\
(45)\end{array}$ & $\mathrm{SD}$ & $\begin{array}{l}\text { Avg. } \\
\text { (9) }\end{array}$ & $\mathrm{SD}$ & $\begin{array}{l}\text { Avg. } \\
\text { (12) }\end{array}$ & $\mathrm{SD}$ & $\begin{array}{l}\text { Avg. } \\
(21)\end{array}$ & $\mathrm{SD}$ & $\begin{array}{l}\text { Avg. } \\
\text { (18) }\end{array}$ & $\mathrm{SD}$ & $\begin{array}{l}\text { Avg. } \\
(50)\end{array}$ & SD & $\begin{array}{l}\text { Avg. } \\
(28)\end{array}$ & SD \\
\hline S & 32.74 & 0.27 & 32.70 & 0.31 & 32.96 & 0.21 & 32.98 & 0.35 & 32.84 & 0.33 & 32.62 & 0.17 & 32.89 & 0.28 & 33.00 & 0.30 & 33.02 & 0.29 & 32.93 & 0.27 \\
\hline $\mathrm{Zn}$ & 63.82 & 2.05 & 64.22 & 1.49 & 64.05 & 2.60 & 65.10 & 0.49 & 61.26 & 2.05 & 65.00 & 0.57 & 63.72 & 1.19 & 60.77 & 5.18 & 62.54 & 3.99 & 64.23 & 1.48 \\
\hline $\mathrm{Fe}$ & 0.67 & 0.49 & 0.68 & 0.36 & 1.33 & 0.75 & 0.67 & 0.33 & 1.87 & 0.39 & 0.91 & 0.32 & 1.57 & 0.73 & 5.08 & 4.27 & 2.97 & 2.53 & 1.36 & 0.63 \\
\hline $\mathrm{Mn}$ & 1.28 & 0.91 & 0.95 & 0.89 & 1.26 & 1.57 & 0.42 & 0.34 & 1.55 & 1.81 & 0.42 & 0.40 & 0.58 & 0.41 & 0.40 & 0.24 & 0.43 & 0.59 & 0.63 & 0.72 \\
\hline $\mathrm{Cu}$ & 0.81 & 0.83 & 0.58 & 0.48 & 1.27 & 1.45 & 0.16 & 0.09 & 1.38 & 0.74 & - & - & 0.66 & 0.57 & 1.21 & 2.11 & 1.91 & 2.97 & 0.67 & 0.55 \\
\hline $\mathrm{Cd}$ & 0.18 & 0.10 & 0.35 & 0.04 & 0.31 & 0.04 & 0.31 & 0.03 & 0.64 & 0.11 & 0.28 & 0.03 & 0.29 & 0.03 & 0.29 & 0.06 & 0.29 & 0.09 & 0.28 & 0.05 \\
\hline In & 0.02 & 0.00 & - & - & 0.03 & 0.02 & - & - & 0.16 & 0.16 & 0.02 & 0.01 & 0.02 & 0.00 & 0.12 & 0.05 & 0.07 & 0.04 & 0.06 & 0.04 \\
\hline $\mathrm{Ag}$ & 0.07 & 0.07 & - & - & 0.06 & 0.05 & 0.03 & 0.02 & 0.20 & 0.17 & - & - & - & - & 0.02 & 0.00 & 0.03 & 0.02 & - & - \\
\hline $\mathrm{Ga}$ & - & - & - & - & - & - & - & - & 0.21 & 0.05 & - & - & - & - & - & - & - & - & - & - \\
\hline $\mathrm{Ge}$ & - & - & - & - & - & - & - & - & 0.03 & 0.01 & - & - & - & - & - & - & - & - & - & - \\
\hline
\end{tabular}

Number of analyses in parentheses;

- not detected or below detection limit. 
from Toyoha $\mathrm{Cu}-\mathrm{Zn}$-In deposits (Japan), also showing Ag up to 1.2 wt.\%.

Cadmium typically ranges from 2400 to $3600 \mathrm{ppm}$. Gallium and Ge were only detected in one sample (DDH33-203), with values up to $2697 \mathrm{ppm}$ and $460 \mathrm{ppm}$, respectively. Silver was detected in some analyses $(\sim 20 \%)$, with values ranging from the detection limit (LOD) to $2490 \mathrm{ppm}$ (Table 2). The In content measured in sphalerite was from $135 \mathrm{ppm}$ (LOD) to $1900 \mathrm{ppm}$, with two values of 3625 and $5940 \mathrm{ppm}$ obtained locally in sphalerite from sample DDH33-203. As observed in Fig. 5b, the highest In contents measured were in sphalerite with the lowest Fe contents.

\section{Chalcopyrite and tetrahedrite-tennantite group minerals}

Apart from the tiny inclusions in sphalerite, chalcopyrite is locally abundant and appears to surround sphalerite and pyrite grains, partially replacing them, or occurs as fracture infillings within sphalerite (Fig. 4d). The tetrahedritetennantite group minerals are commonly associated with chalcopyrite and overgrew chalcopyrite and sphalerite grains (Fig. $4 d$ ), or infilled veinlets. They also form discrete inclusions in chalcopyrite, sphalerite and pyrite. Based on EMPA (Table 3), they have been classified as members of the tetrahedrite-tennantite solid solution, with minor substitution by $\mathrm{Te}$ and $\mathrm{Ag}$ (up to 3.4 wt.\% and 3.2 wt.\%, respectively), and as Ag-rich tetrahedrite (Moëlo et al., 2008), with values of silver between 9 and 20 wt.\% (e.g. analyses DDH31-23 and 24, Table 3). The largest amounts of Te (up to 3.3 wt.\%) were measured in sample DDH33-203, which contains a telluride-rich assemblage. The $\mathrm{Sb} /(\mathrm{Sb}+$ $\mathrm{As})$ and $\mathrm{Ag} /(\mathrm{Ag}+\mathrm{Cu})$ ratios (apfu) vary from 0 to 0.919 and from 0 to 0.327 , respectively, and there is a correlation between the chemical composition of the tetrahedrite-tennantite group minerals and depth of the sample, the $\mathrm{Sb}$ - and $\mathrm{Ag}$-richest varieties occurring in the shallowest samples (Table 3).

The largest amount of $\mathrm{Mn}$ was measured in tennantite from sample DDH36-179 (up to 4 wt.\% $\mathrm{Mn}$ ), although the Ag-rich tetrahedrite from sample DDH36-51 also showed significant amounts of Mn (up to $1.8 \mathrm{wt} . \%$ ). Incorporation of $\mathrm{Mn}$ in synthetic tetrahedrite was reported by Makovicky and KarupMøller (1994). Values of Mn content from natural specimens are rare in the literature, the highest values (up to $6 \mathrm{wt} . \% \mathrm{Mn}$ ) corresponding to samples from epithermal deposits in Romania (Damian, 2003) and Hungary (Dobosi and Nagy, 2000).
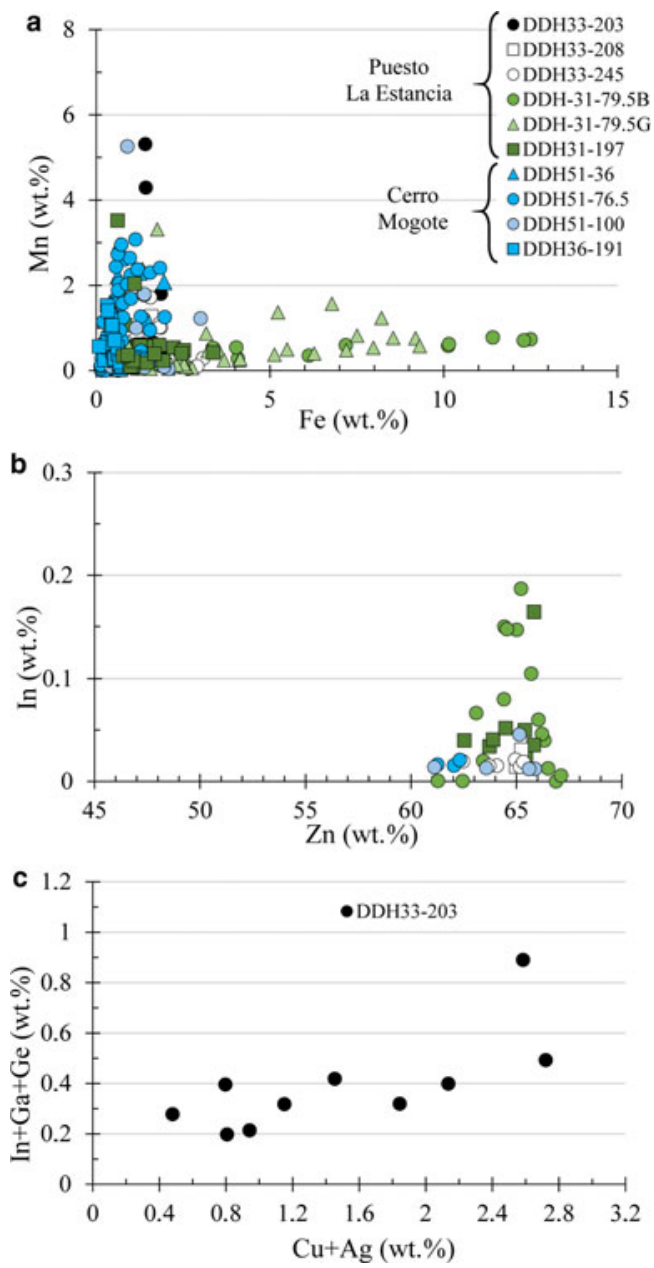

FIG. 5. Binary correlation diagrams (wt.\%) between EMPA of sphalerite from various samples from the Puesto La Estancia and Cerro Mogote prospects. (a) Fe vs. Mn. (b) In vs. Zn. (c) In $+\mathrm{Ga}+\mathrm{Ge} v s . \mathrm{Cu}+\mathrm{Ag}$. Further detail in the text.

\section{Mineralogy and chemistry of Ag-bearing minerals}

The main precious-metal minerals are silver sulfides and sulfosalts, such as acanthite, argyrodite (the Ge-bearing mineral) and the pearceite-polybasite group of minerals, in addition to $\mathrm{Au}-\mathrm{Ag}$ alloy.

Acanthite is the most common Ag-bearing sulfide, occurring as rounded irregular-shaped grains included in earlier-formed sulfides such as pyrite and sphalerite, associated with galena and/or chalcopyrite with curvilinear boundaries between phases (Fig. 6a). Gold-silver alloy, as rounded 
TABLE 3. Selected EMPA results of tetrahedrite-tennantite group minerals from the Puesto La Estancia and Cerro Mogote prospects, La Carolina district.

\begin{tabular}{|c|c|c|c|c|c|c|c|c|c|c|c|c|c|c|c|c|}
\hline \multirow{3}{*}{$\begin{array}{l}\text { Depth (m) } \\
\text { wt.\% }\end{array}$} & \multirow{2}{*}{\multicolumn{2}{|c|}{$\frac{\text { DDH33 }}{203}$}} & \multirow{2}{*}{\multicolumn{2}{|c|}{$\frac{\text { DDH31 }}{79.5}$}} & \multicolumn{6}{|c|}{ DDH36 } & \multicolumn{6}{|c|}{ DDH51 } \\
\hline & & & & & \multicolumn{2}{|c|}{179} & \multicolumn{2}{|c|}{63} & \multicolumn{2}{|c|}{51} & \multicolumn{3}{|c|}{76.5} & \multicolumn{3}{|c|}{36} \\
\hline & & & & & & & & & & & & & & & & \\
\hline $\mathrm{S}$ & 27.36 & 27.01 & 24.06 & 24.55 & 27.77 & 27.80 & 27.54 & 27.32 & 22.94 & 23.10 & 28.16 & 27.99 & 28.59 & 26.29 & 27.36 & 27.01 \\
\hline $\mathrm{Fe}$ & 2.18 & 3.89 & 3.73 & 4.18 & 4.96 & 4.72 & 1.22 & 1.02 & 0.48 & 0.70 & 2.36 & 2.52 & 3.15 & 0.94 & 2.18 & 3.89 \\
\hline $\mathrm{Cu}$ & 42.46 & 43.06 & 24.22 & 24.46 & 40.43 & 42.30 & 42.85 & 41.59 & 26.83 & 26.38 & 41.74 & 42.08 & 41.34 & 40.85 & 42.46 & 43.06 \\
\hline $\mathrm{Mn}$ & n.a. & n.a. & n.a. & n.a. & 3.37 & 2.07 & 0.25 & 0.32 & 1.36 & 0.93 & - & - & - & 0.52 & n.a. & n.a. \\
\hline $\mathrm{Zn}$ & 7.16 & 5.54 & 2.72 & 3.29 & 2.64 & 3.50 & 7.16 & 7.28 & 7.02 & 6.91 & 6.22 & 5.86 & 4.44 & 6.37 & 7.16 & 5.54 \\
\hline As & 17.50 & 16.59 & 4.02 & 4.34 & 18.28 & 18.84 & 20.47 & 18.27 & 1.76 & 2.27 & 20.48 & 20.90 & 21.14 & 14.43 & 17.50 & 16.59 \\
\hline $\mathrm{Sb}$ & 0.93 & 0.92 & 20.54 & 21.77 & 1.94 & 0.65 & - & 3.04 & 24.37 & 23.24 & - & 0.31 & 0.11 & 9.62 & 0.93 & 0.92 \\
\hline $\mathrm{Ag}$ & - & 0.30 & 20.02 & 18.09 & 0.68 & 0.87 & 0.69 & 1.08 & 15.55 & 15.39 & - & 0.19 & 0.42 & 0.63 & - & 0.30 \\
\hline $\mathrm{Te}$ & 2.51 & 3.35 & - & - & - & - & - & - & - & - & - & - & - & - & 2.51 & 3.35 \\
\hline $\begin{array}{l}\text { Total } \\
\text { at. } \%\end{array}$ & 100.10 & 100.66 & 99.29 & 100.67 & 100.08 & 100.73 & 100.19 & 99.92 & 100.30 & 98.93 & 98.96 & 99.84 & 99.19 & 99.65 & 100.10 & 100.66 \\
\hline $\mathrm{S}$ & 12.82 & 12.64 & 13.19 & 13.21 & 12.82 & 12.74 & 12.78 & 12.86 & 12.61 & 12.78 & 13.08 & 12.96 & 13.23 & 12.76 & 12.82 & 12.64 \\
\hline $\mathrm{Fe}$ & 0.58 & 1.05 & 1.17 & 1.29 & 1.31 & 1.24 & 0.33 & 0.27 & 0.15 & 0.22 & 0.63 & 0.67 & 0.84 & 0.26 & 0.58 & 1.05 \\
\hline $\mathrm{Cu}$ & 10.04 & 10.17 & 6.70 & 6.64 & 9.42 & 9.78 & 10.04 & 9.88 & 7.44 & 7.37 & 9.78 & 9.83 & 9.66 & 10.00 & 10.04 & 10.17 \\
\hline $\mathrm{Mn}$ & & & & & 0.91 & 0.55 & 0.07 & 0.09 & 0.44 & 0.30 & & & & 0.15 & & \\
\hline $\mathrm{Zn}$ & 1.64 & 1.27 & 0.73 & 0.87 & 0.60 & 0.79 & 1.63 & 1.68 & 1.89 & 1.88 & 1.42 & 1.33 & 1.01 & 1.52 & 1.64 & 1.27 \\
\hline As & 3.51 & 3.32 & 0.94 & 1.00 & 3.61 & 3.69 & 4.06 & 3.68 & 0.41 & 0.54 & 4.07 & 4.14 & 4.19 & 3.00 & 3.51 & 3.32 \\
\hline $\mathrm{Sb}$ & 0.12 & 0.11 & 2.97 & 3.08 & 0.24 & 0.08 & 0.00 & 0.38 & 3.53 & 3.39 & 0.01 & 0.04 & 0.01 & 1.23 & 0.12 & 0.11 \\
\hline $\mathrm{Ag}$ & 0.00 & 0.04 & 3.26 & 2.89 & 0.09 & 0.12 & 0.10 & 0.15 & 2.54 & 2.53 & 0.00 & 0.03 & 0.06 & 0.09 & 0.00 & 0.04 \\
\hline $\mathrm{Te}$ & 0.30 & 0.39 & & & & & & & & & & & & & 0.30 & 0.39 \\
\hline $\mathrm{Sb} /(\mathrm{Sb}+\mathrm{As})$ & 0.03 & 0.03 & 0.76 & 0.76 & 0.06 & 0.02 & 0.00 & 0.09 & 0.90 & 0.90 & 0.00 & 0.01 & 0.00 & 0.29 & 0.03 & 0.03 \\
\hline $\mathrm{Ag} /(\mathrm{Ag}+\mathrm{Cu})$ & 0.00 & 0.00 & 0.33 & 0.30 & 0.01 & 0.01 & 0.01 & 0.02 & 0.25 & 0.25 & 0.00 & 0.00 & 0.01 & 0.01 & 0.00 & 0.00 \\
\hline
\end{tabular}

The analyses are sorted by drill core (first row) and by the depth of the sample in metres (second row). The $\mathrm{Sb} /(\mathrm{Sb}+\mathrm{As})$ and $\mathrm{Ag} /(\mathrm{Ag}+\mathrm{Cu}) \mathrm{ratios}$ increase towards shallower samples. Atom ratios were calculated on the basis of 29 atoms per formula unit.

- below detection limit

n.a.: not analysed. 



FIG. 6. Photomicrographs under plane-polarized and reflected light. (a) Rounded acanthite (ac) inclusions, often with galena and chalcopyrite, within sphalerite crystals. Sample DDH36-191. (b) Pearceite-polybasite (prc-plb) group minerals replacing galena. (c) Argyrodite grains (arg) filling interstitial cavities between sphalerite and quartz crystals, along with pyrite (py), chalcopyrite (ccp) and Au-Ag alloy (el). There is also covellite (cv) after chalcopyrite (same sample as in $a$ ). $(d)$ Pyrite (py) overgrown and partially replaced by galena (gn) and sphalerite (sp). Pyrite crystals show abundant irregular and rounded inclusions of Ag-bearing minerals (black arrows). Sample DDH31-79.5. (e) Detail from part $(d)$ showing an intergrowth between hessite (hs, greyish white with a brownish shade) and cervelleite (crv, light blue). $(f)$ Image of the telluride-rich chalcopyrite bearing sample DDH33-203 from the Puesto La Estancia prospect. 
micro-inclusions, is also associated spatially with acanthite. Based on petrographic observations, another type of acanthite replaced pearceitepolybasite minerals, showing a porous and dusty appearance (Fig. 6b). Quantitative microanalysis of acanthite was quite difficult because of the destabilization of the mineral under the electron beam, especially in the dusty acanthite, and the results of just a single analysis are given in Table 4.

Argyrodite is commonly associated with sphalerite and galena. It occurs as irregular grains, up to $40 \mu \mathrm{m}$ in size, included or attached to the margin of sphalerite grains (Fig. $6 c$ ), or as rounded inclusions in pyrite (Fig. $6 d$ ). The EMPA show up to 2 wt.\% $\mathrm{Zn}$ and up to $1.2 \mathrm{wt} . \% \mathrm{Hg}$ (Table 4).

The minerals of the pearceite-polybasite group appear as small rounded inclusions in pyrite (Fig. $7 d$ ) or as irregular grains that replaced galena (Fig. $6 b$ and the BSE image in Fig. 7b). Taking into account that only the chemical composition is available, classification suggested by Bindi et al. (2007) was used here: phases with As $>$ Sb should be named pearceite $\left[\mathrm{Ag}_{9} \mathrm{CuS}_{4}\right]\left[(\mathrm{Ag}, \mathrm{Cu})_{6}(\mathrm{As}, \mathrm{Sb})_{2} \mathrm{~S}_{7}\right]$; phases with $\mathrm{Sb}>\mathrm{As}$ should be named polybasite $\left[\mathrm{Ag}_{9} \mathrm{CuS}_{4}\right]\left[(\mathrm{Ag}, \mathrm{Cu})_{6}(\mathrm{Sb}, \mathrm{As})_{2} \mathrm{~S}_{7}\right]$ (Table 4).

With regard to gold-silver alloys: free gold is rarely detectable at the microscopic scale. The gold grains observed vary from $<1 \mu \mathrm{m}$ to $20 \mu \mathrm{m}$ in size, and occur as inclusions within sphalerite and pyrite in association with acanthite, argyrodite and pearceite-polybasite minerals (Fig. 6c). Due to its small size there is only one EMPA result, with an $\mathrm{Ag}$ content of $\sim 36 \mathrm{wt} . \%$, although qualitative SEM-EDAX analyses show $\mathrm{Ag}$ contents of $\sim 25 \mathrm{wt} . \%$. Gold was not detected in pyrite so if there is 'invisible gold', it would be in amounts which are below the detection limit (250 ppm).

In the Puesto La Estancia prospect, the mineral paragenesis is locally enriched in Se and Te. The silver telluride, hessite $\left(\mathrm{Ag}_{2} \mathrm{Te}\right)$, occurs instead of acanthite. Hessite has been found intergrown with Se-rich cervelleite $\left(\mathrm{Ag}_{4} \mathrm{TeS}\right.$, Fig. $\left.6 d, e\right)$, although Se-cervelleite also occurs as inclusions in pyrite sometimes associated with $\mu \mathrm{m}$-sized Au-Ag alloy (Fig. 7a). Moreover, Te- and Se-bearing examples of argyrodite and polybasite-pearceite group minerals, have been detected by EMPA or, in the case of very small phases, by SEM-EDAX analyses (Tables 4 and 5).

The pearceite-polybasite group minerals show variable amounts of both $\mathrm{Te}$ and $\mathrm{Se}$ (3.5-4.4 wt.\% Te, 0.16-2.3 wt.\% Se, Table 5). The lowest Se contents $(<0.2 \mathrm{wt} . \%)$ were measured in the Cerro Mogote prospect (sample DDH51-102 in Table 5), although only one analysis is suitable. Moreover, the EMPA of the sample from the Puesto La Estancia prospect (sample DDH31-79.5 in Table 5) show up to $3572 \mathrm{ppm} \mathrm{Au}$, although due to the resulting high LOD for $\mathrm{Au}(1870 \mathrm{ppm})$ in the analysis of these sulfides, most of the values were below the detection limit.

Benleonardite $\left[\mathrm{Ag}_{15} \mathrm{Cu}\left(\mathrm{As}, \mathrm{Sb}_{2} \mathrm{~S}_{7} \mathrm{Te}_{4}\right]\right.$ and alburnite $\left(\mathrm{Ag}_{8} \mathrm{GeTe}_{2} \mathrm{~S}_{4}\right)$, the Te-rich members of the pearceite-polybasite and argyrodite group, respectively, were identified by SEM imaging and only SEM-EDAX analyses are shown in Table 4. Both minerals are associated spatially with galena and hessite (Fig. 7c,d).

One of the samples from the Puesto La Estancia prospect was especially rich in $\mathrm{Te}$ and the paragenesis of accessory minerals is composed of telluride minerals other than hessite including: sylvanite $\left[(\mathrm{Ag}, \mathrm{Au})_{2} \mathrm{Te}_{4}\right]$, petzite $\left(\mathrm{Ag}_{3} \mathrm{AuTe}_{2}\right)$, stutzite $\left[\mathrm{Ag}_{5-\mathrm{x}} \mathrm{Te}_{3},(x=0.24-0.36)\right]$, altaite $(\mathrm{PbTe})$, tellurobismuthite $\left(\mathrm{Bi}_{2} \mathrm{Te}_{3}\right)$ and volynskite $\left(\mathrm{AgBiTe}_{2}\right)$. They occur as aggregates, up to $50 \mu \mathrm{m}$ in diameter, associated with chalcopyrite (Fig. $6 f$ ). Some of these aggregates are complex, including several different minerals or only one or two phases (Fig. 7e,f). Galena is also present in these aggregates (Fig. 7e). A compilation of the EMPA performed on these tellurides is presented in Table 6 and show anomalous $\mathrm{Fe}$ and $\mathrm{Cu}$ contents by secondary fluorescence from nearby chalcopyrite, due to the usually small size of the tellurides.

\section{Discussion}

The mineral paragenesis and textures observed (Fig. 8) in samples from the Cerro Mogote and Puesto La Estancia prospects suggest the existence of different pulses of fluids and fracturing supported by open-space filling and brecciation textures in mineralized veins and breccias and by the variation in the chemical conditions of fluids during mineralization. Fluctuation in $\mathrm{pH}$ between slightly acidic and neutral to more alkaline conditions is suggested by the presence of K-feldspar alternating with illite, and the abundance of $\mathrm{Mn}-\mathrm{Fe}-\mathrm{Mg}( \pm \mathrm{Ca})$ carbonates, especially in the Puesto La Estancia. In addition, the carbonate deposition would be favoured by an increase in oxygen fugacity $\left(f_{\mathrm{O}_{2}}\right)$ and $\mathrm{CO}_{2}$ concentration (e.g. Damian, 2003; Canet et al., 2009; Chinchilla et al., 2016).

The formation of zoned pyrite, with As-rich cores and $\mathrm{Cu}$-rich bands, also indicates compositional variations in fluids as it grew. Similar 
TABLE 4. Selected EMPA results of Ag-bearing minerals from various samples of drill cores from the Puesto La Estancia and Cerro Mogote prospects, La Carolina district.

\begin{tabular}{|c|c|c|c|c|c|c|c|c|c|c|c|c|c|c|c|}
\hline \multirow{2}{*}{$\begin{array}{l}\text { wt.\% } \\
\text { S }\end{array}$} & \multirow{2}{*}{$\begin{array}{c}\text { Acanthite } \\
15.47\end{array}$} & \multicolumn{3}{|c|}{ Argyrodite } & \multirow{2}{*}{$\frac{\text { Alburnite }(*)}{10.05}$} & \multicolumn{2}{|c|}{ Pearceite } & \multicolumn{2}{|c|}{ Polybasite } & \multirow{2}{*}{$\frac{\text { Benleonardite }(*)}{9.44}$} & \multicolumn{3}{|c|}{ Se-Cervelleite } & \multicolumn{2}{|c|}{ Se-Hessite } \\
\hline & & 18.93 & 16.11 & 17.11 & & 16.40 & 16.44 & 15.09 & 15.44 & & 3.36 & 2.57 & 5.37 & - & 1.38 \\
\hline $\mathrm{Fe}$ & 1.14 & - & - & 0.28 & & - & - & 0.05 & - & & 0.82 & 0.34 & 1.56 & - & 0.08 \\
\hline $\mathrm{Cu}$ & 3.97 & 0.38 & 0.48 & 0.48 & & 4.99 & 5.47 & 3.72 & 5.08 & 1.18 & - & - & - & - & 0.03 \\
\hline $\mathrm{Zn}$ & 0.05 & 0.21 & 0.27 & 2.10 & & 0.52 & 0.53 & & & & 0.48 & 0.82 & - & 0.48 & 0.70 \\
\hline As & 0.00 & 0.00 & - & - & & 5.32 & 6.01 & 1.06 & 1.02 & 3.95 & - & - & - & - & - \\
\hline $\mathrm{Ge}$ & 0.00 & 6.46 & 5.88 & 6.27 & 2.07 & - & - & - & - & & - & - & - & - & - \\
\hline $\mathrm{Se}$ & 0.70 & - & 0.10 & 0.09 & & - & - & - & - & & 3.02 & 3.43 & 5.48 & 0.37 & 1.59 \\
\hline $\mathrm{Ag}$ & 77.88 & 73.52 & 77.82 & 71.75 & 69.06 & 70.68 & 69.33 & 72.10 & 69.53 & 65.25 & 64.56 & 65.33 & 67.59 & 63.15 & 63.33 \\
\hline $\mathrm{Sb}$ & 0.00 & - & - & 0.00 & & 2.14 & 1.35 & 7.56 & 7.78 & & 0.12 & 0.18 & & 0.18 & 0.18 \\
\hline $\mathrm{Te}$ & 0.10 & 0.12 & - & - & 18.82 & - & - & - & - & 20.19 & 26.92 & 27.65 & 19.37 & 35.24 & 33.38 \\
\hline $\mathrm{Hg}$ & - & 0.73 & 0.67 & 1.18 & & - & - & - & - & & - & - & - & - & - \\
\hline Total & $\begin{array}{l}99.32 \\
\text { to } 3 \text { at. }\end{array}$ & 100.34 & $\begin{array}{l}101.32 \\
\text { to } 15 \text { at. }\end{array}$ & 99.25 & $\begin{array}{l}100.00 \\
\text { to } 15 \text { at. }\end{array}$ & 100.04 & $\begin{array}{l}99.13 \\
\text { to } 29\end{array}$ & $\begin{array}{l}99.57 \\
\text { at. }\end{array}$ & 98.86 & $\begin{array}{l}100.01 \\
\text { to } 29 \text { at. }\end{array}$ & 99.27 & $\begin{array}{l}100.31 \\
\text { to } 6 \text { at. }\end{array}$ & 99.38 & $\begin{array}{r}99.78 \\
\text { to }\end{array}$ & $\begin{array}{l}100.71 \\
\text { at. }\end{array}$ \\
\hline S & 1.12 & 6.44 & 5.71 & 5.99 & 4.16 & 11.06 & 11.09 & 10.71 & 10.88 & 7.56 & 0.64 & 0.50 & 0.96 & 0.01 & 0.14 \\
\hline $\mathrm{Fe}$ & 0.05 & & & 0.06 & & & & 0.02 & & & 0.09 & 0.04 & 0.16 & & \\
\hline $\mathrm{Cu}$ & 0.14 & 0.06 & 0.09 & 0.08 & & 1.70 & 1.86 & 1.33 & 1.807 & 0.48 & & & & & \\
\hline $\mathrm{Zn}$ & & 0.04 & 0.05 & 0.36 & & & & & & & 0.05 & 0.08 & & & \\
\hline As & & & & & & 1.53 & 1.73 & 0.32 & 0.31 & 1.35 & & & & & \\
\hline $\mathrm{Ge}$ & & 0.97 & 0.92 & 0.97 & 0.38 & & & & & & & & & & \\
\hline $\mathrm{Se}$ & 0.02 & & 0.01 & 0.01 & & & & & & & 0.24 & 0.27 & 0.40 & 0.02 & 0.07 \\
\hline $\mathrm{Ag}$ & 1.67 & 7.44 & 8.19 & 7.46 & 8.50 & 14.16 & 13.90 & 15.20 & 14.56 & 15.54 & 3.68 & 3.76 & 3.60 & 2.00 & 1.90 \\
\hline $\mathrm{Sb}$ & & & & & & 0.38 & 0.24 & 1.41 & 1.44 & & 0.01 & 0.01 & & 0.01 & \\
\hline $\mathrm{Te}$ & & 0.01 & & & 1.96 & & & & & 4.07 & 1.30 & 1.35 & 0.87 & 0.94 & 0.85 \\
\hline $\mathrm{Hg}$ & & 0.04 & 0.04 & 0.07 & & & & & & & & & & & \\
\hline
\end{tabular}

- below detection limit.

*SEM-EDAX analyses. 

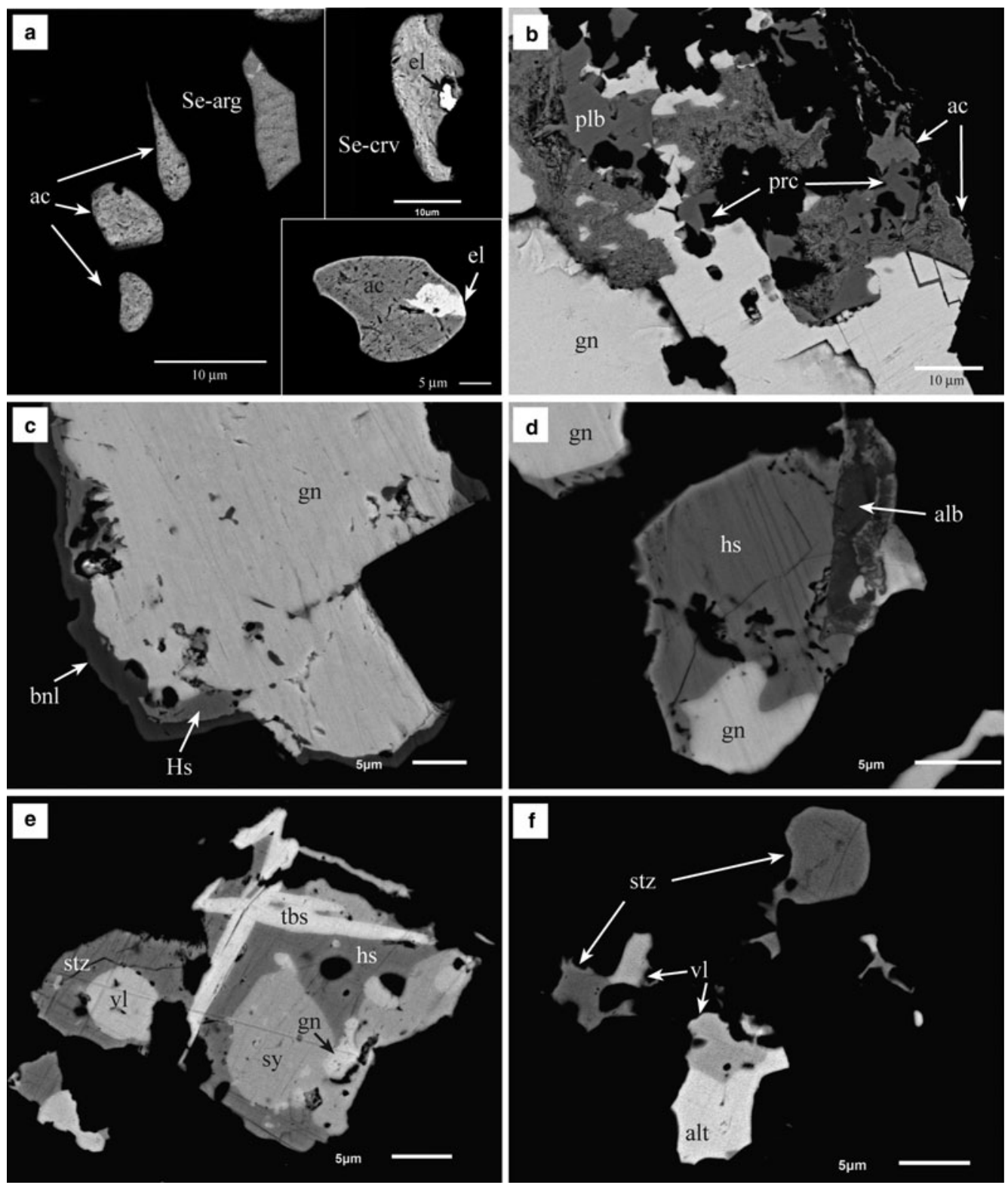

FIG. 7. Back-scattered electron images (BSE) of samples shown in Fig. 6. (a) Rounded and irregular inclusions of acanthite (ac), Se-bearing argyrodite (Se-arg) and Se-bearing cervelleite (Se-crv). Some inclusions contain minute grains of Au-Ag alloy (el). The BSE image, bottom right, is from sample DDH36-191; the others are from sample DDH31-79.5. (b) Detail of Fig. $6 b$. Galena has been partially replaced by pearceite ( $\mathrm{prc}$ ) and polybasite ( $\mathrm{plb}$ ), which are also replaced by acanthite (ac) with a porous, dusty appearance. (c) Galena surrounded by hessite (hs) and benleonardite (bnl). Sample DDH31-79.5. (d) A small grain of alburnite (alb) associated with hessite and galena. Sample DDH3179.5. (e) Complex aggregate of tellurobismuthite (tbs), hessite (hs), stutzite (stz), sylvanite (sy), volynskite (vl) and galena (gn). Sample DDH33-203. $(f)$ Irregular inclusions of tellurides in chalcopyrite including stutzite (stz),

volynskite (vl) and altaite (alt) instead of galena. Sample DDH33-203. 
TABLE 5. Electron microprobe analyses of Te- and Se-bearing pearceite-polybasite.

\begin{tabular}{|c|c|c|c|c|c|c|c|c|c|}
\hline \multirow[b]{2}{*}{ wt.\% } & \multicolumn{8}{|c|}{ DDH31-79.5 } & \multirow{2}{*}{$\begin{array}{c}\text { DDH51-102 } \\
2\end{array}$} \\
\hline & 2 & 3 & 5 & 6 & 7 & 8 & 9 & 25 & \\
\hline S & 12.43 & 12.77 & 13.09 & 13.66 & 13.72 & 13.09 & 12.92 & 12.19 & 14.71 \\
\hline $\mathrm{Fe}$ & 1.17 & 1.52 & 0.30 & 0.30 & 1.01 & 0.97 & 1.14 & 1.06 & 1.85 \\
\hline $\mathrm{Cu}$ & 3.59 & 4.06 & 4.10 & 4.04 & 3.78 & 3.89 & 3.88 & 3.96 & 3.98 \\
\hline $\mathrm{Zn}$ & - & - & - & - & - & 0.14 & - & - & - \\
\hline As & 3.53 & 3.90 & 3.30 & 3.22 & 4.46 & 2.74 & 4.44 & 3.88 & 4.94 \\
\hline $\mathrm{Sb}$ & 3.73 & 3.74 & 4.86 & 4.70 & 2.79 & 4.93 & 2.66 & 3.78 & 2.76 \\
\hline $\mathrm{Se}$ & 2.13 & 2.21 & 1.36 & 1.26 & 1.97 & 0.98 & 2.05 & 2.27 & 0.16 \\
\hline $\mathrm{Te}$ & 4.28 & 4.37 & 3.56 & 3.51 & 3.91 & 4.03 & 3.80 & 3.76 & 3.80 \\
\hline $\mathrm{Ag}$ & 68.84 & 67.22 & 68.03 & 69.16 & 68.03 & 68.89 & 69.13 & 68.12 & 68.01 \\
\hline $\mathrm{Au}$ & - & - & 0.33 & 0.19 & 0.36 & - & 0.32 & - & - \\
\hline Total & 99.70 & 99.77 & 98.91 & 100.03 & $\begin{array}{l}100.01 \\
\text { to } 29 \text { atoms }\end{array}$ & 99.65 & 100.33 & 98.99 & 100.22 \\
\hline S & 9.06 & 9.19 & 9.57 & 9.80 & 9.74 & 9.48 & 9.25 & 8.94 & 10.19 \\
\hline $\mathrm{Fe}$ & 0.49 & 0.63 & 0.13 & 0.12 & 0.41 & 0.40 & 0.47 & 0.44 & 0.74 \\
\hline $\mathrm{Cu}$ & 1.32 & 1.47 & 1.51 & 1.46 & 1.35 & 1.42 & 1.40 & 1.46 & 1.40 \\
\hline As & 1.10 & 1.20 & 1.03 & 0.99 & 1.36 & 0.85 & 1.36 & 1.22 & 1.47 \\
\hline $\mathrm{Sb}$ & 0.72 & 0.71 & 0.93 & 0.89 & 0.52 & 0.94 & 0.50 & 0.73 & 0.50 \\
\hline $\mathrm{Te}$ & 0.78 & 0.79 & 0.65 & 0.63 & 0.70 & 0.73 & 0.68 & 0.69 & 0.66 \\
\hline $\mathrm{Se}$ & 0.63 & 0.65 & 0.40 & 0.37 & 0.57 & 0.29 & 0.59 & 0.68 & 0.04 \\
\hline $\mathrm{Ag}$ & 14.91 & 14.37 & 14.78 & 14.74 & 14.35 & 14.83 & 14.71 & 14.84 & 14.00 \\
\hline $\mathrm{Au}$ & & & 0.04 & 0.02 & 0.04 & & 0.04 & & \\
\hline
\end{tabular}

- below detection limit. 
TABLE 6. Selected EMPA results of tellurides from the Puesto La Estancia prospect, La Carolina district.

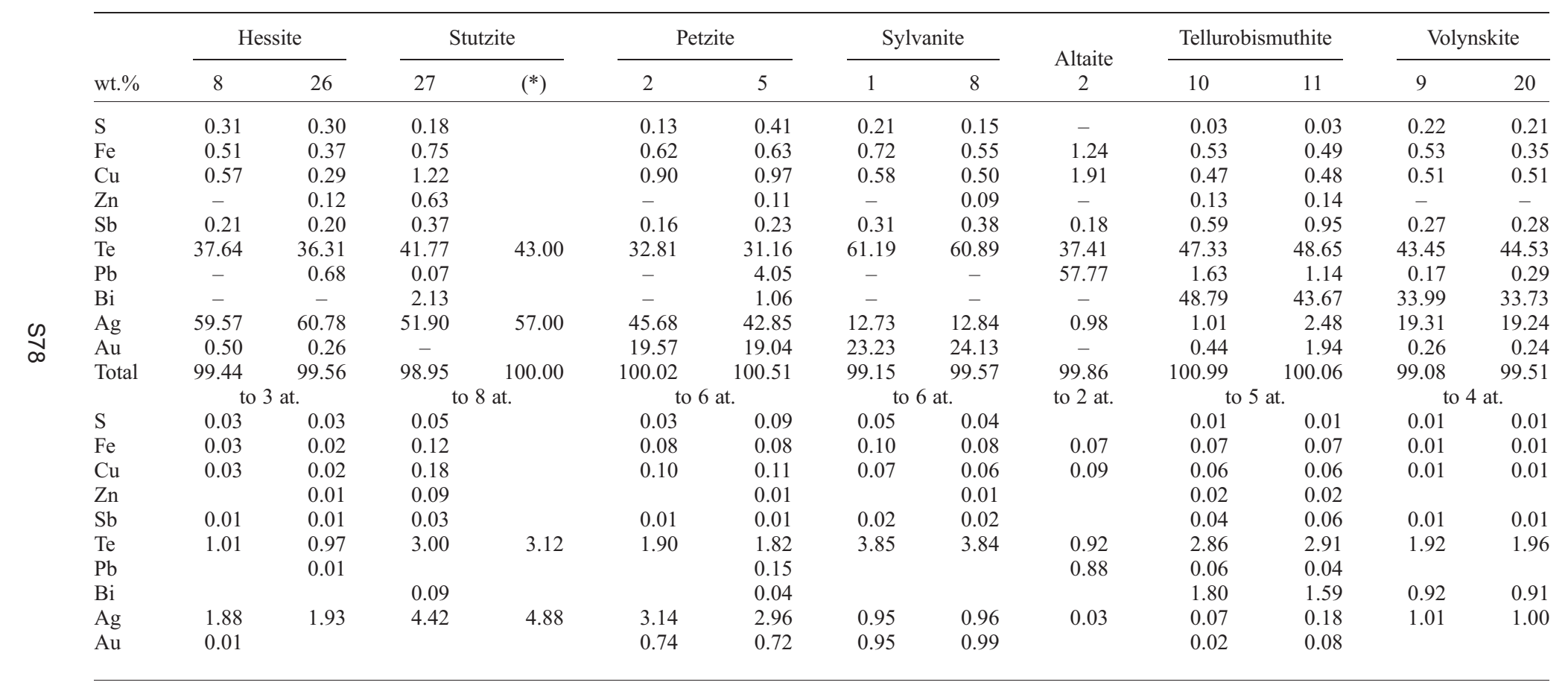

- below detection limit.

*SEM-EDAX analysis. 


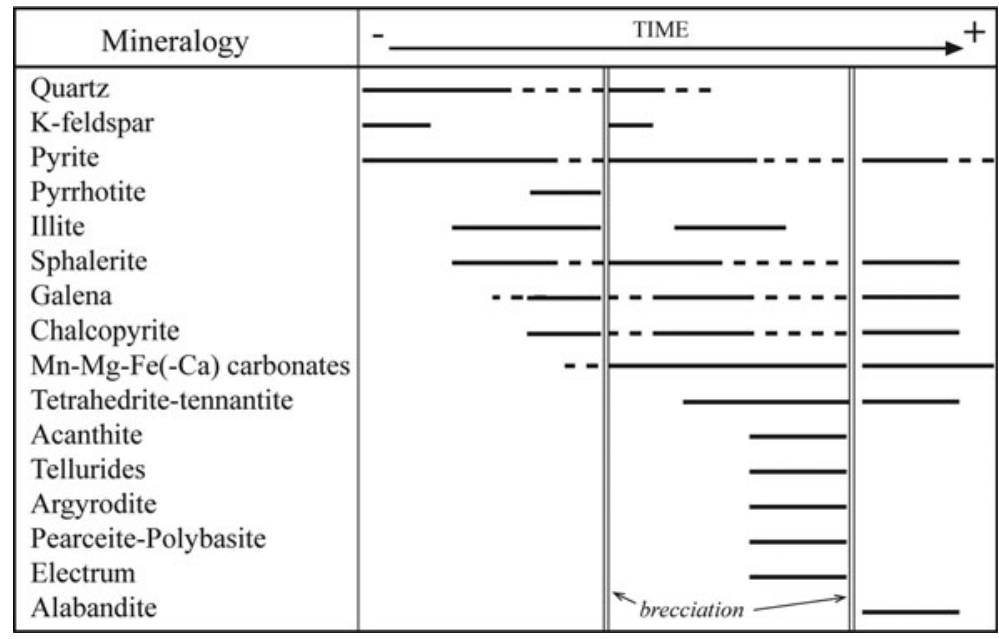

FIG. 8. Paragenetic sequence of the prospects studied (Cerro Mogote and Puesto la Estancia).

alternating As- and $\mathrm{Cu}$-rich bands in pyrite crystals were described by Deditius et al. (2009) from the Pueblo Viejo and Yanacocha high-epithermal deposits, and Franchini et al. (2015), from the Agua Rica epithermal-porphyry deposit. Deditius et al. (2009) interpreted these changes in fluid composition as the result of mixing of a pyriteforming fluid and magmatic vapour that invaded the main hydrothermal system episodically. In the deposits studied here, during the early pyrite deposition, fluids would have been characterized by a sulfur fugacity above the equilibrium boundary of pyrite $+\mathrm{As}=$ arsenopyrite, because arsenopyrite was not deposited. During the main base-metal ore deposition, fluids would have progressed to lower sulfur fugacities that favoured the precipitation of Fe-rich sphalerite and pyrrhotite. However, a subsequent increase in sulfur fugacity would support the deposition of a new generation of $\mathrm{Fe}$ poor sphalerite and the final deposition of pyrite and alabandite, in breccia cavities.

\section{Trace elements in sphalerite}

Apart from Fe, EMPA of sphalerite show that it contains variable amounts of $\mathrm{Mn}, \mathrm{Cu}, \mathrm{Cd}, \mathrm{In}, \mathrm{Ga}$, $\mathrm{Ge}$ and Ag. In most of the samples, the In contents $>$ LOD were in yellowish, Fe-poor sphalerite, and there is no correlation between In and other trace elements including $\mathrm{Cu}, \mathrm{Mn}$ and $\mathrm{Cd}$. Nevertheless, the highest In contents (up to $5940 \mathrm{ppm}$ ) were measured in sphalerite grains from the DDH33-203 sample that also show $\mathrm{Ga}$ and $\mathrm{Ge}$ concentrations $>$ LOD. In this sample, there is a correlation between In and $\mathrm{Cu}+\mathrm{Ag}$, which improves if $\mathrm{Ga}$ and $\mathrm{Ge}$ are also considered (Fig. 5c). This suggests a coupled substitution mechanism resulting in monovalent cation enrichment (i.e. $\mathrm{Ag}^{+}$and $\mathrm{Cu}^{+}$) with respective tri- and tetravalent cation enrichments (e.g. $\mathrm{Sb}^{3+}, \mathrm{Ga}^{3+}, \mathrm{In}^{3+}, \mathrm{As}^{3+}, \mathrm{Ge}^{4+}$ and $\left.\mathrm{Sn}^{4+}\right)(\mathrm{Cook}$ et al., 2009). The Mn content of sphalerite is, in general, greater in samples from the Cerro Mogote prospect than from the Puesto La Estancia prospect, which also correlates with the abundance of Mnrich carbonates in the latter.

Several recent studies exist of trace-element contents in sphalerite from different types of $\mathrm{Pb}$ Zn deposits (e.g. Moura et al., 2007; Cook et al., 2009, 2011; Ye et al., 2011; Belissont et al., 2014; Frenzel et al., 2016) that have shown significant differences in the concentrations of the elements In, $\mathrm{Ga}$ and, $\mathrm{Ge}$ in sphalerite. The authors mentioned previously the differences in formation temperatures, with greater In contents associated with magma-related deposits (skarns, granite-related mineralization, epithermal and massive sulfide deposits), whereas the presence of $\mathrm{Ga}$ and $\mathrm{Ge}$ in sphalerite is associated with low-temperature hydrothermal deposits (e.g. carbonate-replacement MVT deposits). However, Sahlström et al. (2017) recently published LA-ICP-MS high concentrations of $\mathrm{Ga}$ and $\mathrm{Ge}$ in In-rich sphalerite from the intermediate-sulfidation stage assemblage of the Mt Carlton high sulfidation epithermal deposit. These authors observed a positive correlation in the $\mathrm{Cu}+$ 
Ag vs. In + Ga plot similar to that observed in sphalerite of sample DDH33-203 from Puesto La Estancia. In the Mt Carlton deposit, the highest concentrations of In (up to $2169 \mathrm{ppm}$ ) and Ga (up to $2829 \mathrm{ppm}$ ) in sphalerite occur in the proximal, $\mathrm{Cu}$-rich parts of the deposit (Sahlström et al., 2017). Other examples of sphalerite enriched in In$\mathrm{Ga} \pm \mathrm{Ge}$ from $\mathrm{Cu}$-rich assemblages of intermediatesulfidation deposits have been also reported (e.g. Palai-Islica, Carrillo-Rosúa et al., 2008; Rosia Montana, Cook et al., 2009). The high Cu activity in the ore fluid is a strong control on In enrichment and, to a lesser degree, Ga enrichment in sphalerite, allowing the extensive incorporation of these elements in couple substitution with $\mathrm{Cu}$ (Sahlström et al., 2017; Frenzel et al., 2016).

The presence of $\mathrm{Ge}$ and $\mathrm{Ga}$ in hydrothermal fluids probably derives from enrichment during the fractional crystallization processes of igneous rocks (Breiter et al., 2013), or they were derived from the country rocks, particularly from those containing organic material (Bernstein, 1985; Höll et al., 2007). According to the latter authors, the behaviour of $\mathrm{Ge}$ appears to be dependent on the sulfur fugacity conditions whereby Ge enters the structure of sphalerite in low to moderate sulfur activity and forms its own phases under higher fugacity of sulfur. High-sulfidation states favour Ge concentration through the formation of the thiocomplex $\left[\mathrm{GeS}_{4}\right]^{4-}$ and thiogermanates, preferably as $\mathrm{Cu}-$ and $\mathrm{Ag}$-sulfide minerals, e.g. germanite, renierite, briartite and argyrodite (Bernstein, 1985; Paar et al., 2004a; Paar and Putz, 2005).

In the current study, the enrichment of $\mathrm{Ge}$ is mainly associated with the presence of argyrodite, whereas the Ge content in sphalerite is commonly low, below the detection limit (120 ppm). Only sphalerite from sample DDH33-203 from the Puesto La Estancia prospect shows Ge contents above the detection limit. The presence of graphite in samples from the metamorphic basement suggests that the increase of $\mathrm{Ge}$ and $\mathrm{Ga}$ in the hydrothermal fluid could be due to the leaching of country rocks, although a magmatic source cannot be ruled out.

\section{Telluride paragenesis}

The enrichment of certain trace ore elements, such as $\mathrm{Te}, \mathrm{Se}$ and $\mathrm{Bi}$, in the Puesto La Estancia and Cerro Mogote prospects, emphasizes a likely magmatic contribution to the mineralized fluid (Cooke and McPhail, 2001). Selenium is a highly chalcophile element and substitutes readily for sulfur in sulfide minerals (Simon et al., 1997). Tellurium is less compatible in sulfides than $\mathrm{Se}$ due to the greater atomic radius of the telluride ion $\left(\mathrm{Te}^{2-}=2.11 \AA\right)$ than that of the selenide $\left(\mathrm{Se}^{2-}=\right.$ $1.88-1.90 \AA)$ and sulfide ions $\left(\mathrm{S}^{2-}=1.56-1.78 \AA\right.$ ). Therefore, Te will commonly tend to form tellurides during later stages of mineralization when the $f_{T_{2}} / f_{\mathrm{s}_{2}}$ ratio in the ore fluid increases as a result of deposition of early sulfides (Simon et al., 1997). An approximation to the $f_{\mathrm{Te}}$, and $f_{\mathrm{S}}$ conditions for the Ag-Au paragenesis of the Puesto La Estancia prospect is shown in Fig. 9 (after Afifi et al., 1988), at $250^{\circ} \mathrm{C}$. No data exist to constrain the exact temperature for the telluride precipitation, but this temperature is reasonably expected for this epithermal systems. Nevertheless, although the absolute $f \mathrm{Te}_{2}$ and $f \mathrm{~S}_{2}$ values will shift with changing temperature, the topologies of these diagrams are essentially constant and they are useful for comparison of telluride assemblages (Afifi et al., 1988). The low $f_{\mathrm{Te}_{2}}$ necessary to precipitate hessite explains the common occurrence of this telluride in the Ag-rich paragenesis in association with acanthite and Au-Ag alloy ( \pm cervelleite). In the telluride paragenesis, the absence of Au-Ag alloy may be used to define the lower limit of $f_{\mathrm{Te}_{2}}$. The lower limit would correspond approximately to the hessite- $\gamma$ reaction (Fig. 9) because sylvanite may be formed by the breakdown of the phase $\gamma$ [( $\mathrm{Au}$, Ag) $)_{1.9} \mathrm{Te}$ ] (Affifi et al., 1988). This limit indicates an increment of $\sim 8 \log$ units of $\mathrm{Te}_{2}$ fugacity. The presence of both altaite and galena defines $f_{\mathrm{Te}_{2}}$ and $f_{\mathrm{s}_{2}}$ conditions on the galena-altaite reaction, within the stability field of pyrite (Fig. 9).

The textural relationships observed in Puesto La Estancia suggest that tellurides post-date the formation of sulfide minerals (Fig. 8), which is in agreement with the interpretation of Simon et al. (1997). Larger $f_{\mathrm{Te}_{2}}$ values in the mineralizing fluids can be produced by rejuvenation through the incorporation of magmatic fluids. Oxidized magmatic fluids can carry high levels of Te over a wide range of $\mathrm{pH}$ values (Cooke and McPhail, 2001; Grundler et al., 2013), whereas the solubility of Te is low under reducing conditions at acidic to neutral $\mathrm{pHs}$, with Te mainly concentrated in the vapour (Grundler et al., 2013). According to those authors, at mildly reducing conditions (hematite-pyrite stability) and alkaline pHs, Au-rich ( $\geq 300 \mathrm{ppb}$ $\mathrm{Au} ; \mathrm{Au}$ transported as $\mathrm{Au}(\mathrm{HS})_{2}^{-}$) solutions can also carry significant Te. In addition to that, Manske et al. (2004) suggested a contribution of magmatic vapour for the origin of the Te-rich paragenesis in the intermediate-sulfidation epithermal deposit of 


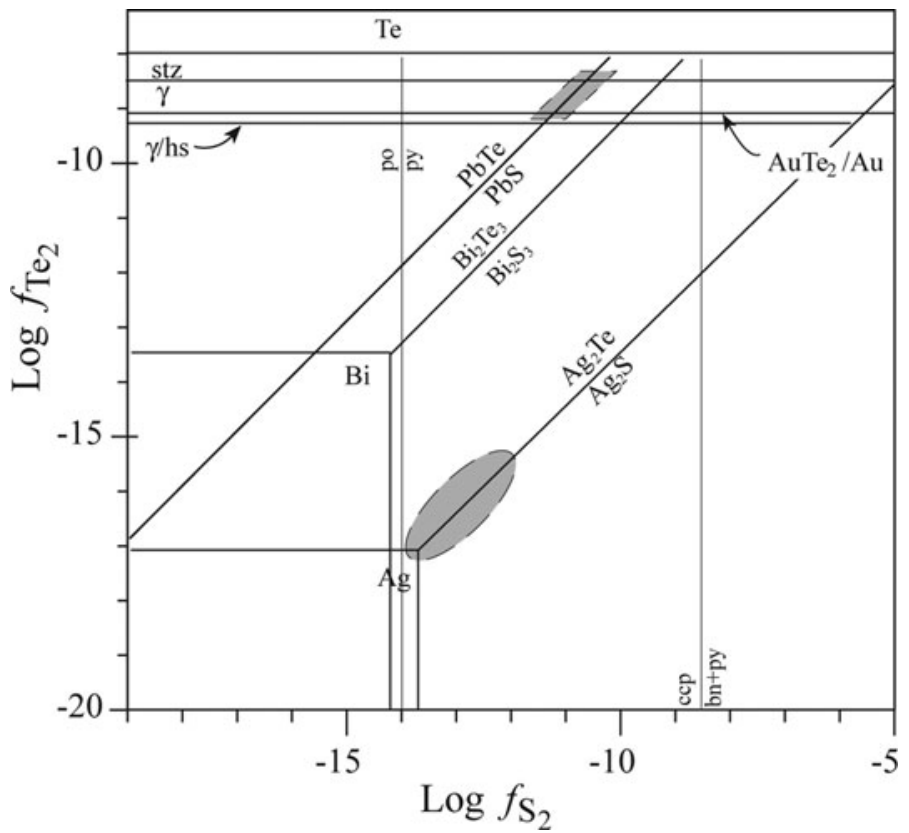

FIG. 9. Telluride-sulfide stability diagram, at $250^{\circ} \mathrm{C}$ (after Afifi et al., 1988), for different Ag parageneses observed in ore samples from the Puesto La Estancia prospect. Abbreviations: bn: bornite, ccp: chalcopyrite, hs: hessite, po: pyrrhotite, py: pyrite, stz: stutzite, $\gamma$ : phase $(\mathrm{Au}, \mathrm{Ag})_{1.9} \mathrm{Te}$.

Rosia Montana (Romania). In the case of Puesto La Estancia, telluride mineralization is hosted by an andesitic lava with argillic alteration. X-ray diffraction shows that the altered host-rock consists of quartz, illite, kaolinite and dickite (GallardEsquivel, 2015). This alteration suggests more acidic $\mathrm{pH}$ conditions that could reduce tellurium solubility in the hydrothermal fluid. But at this level of knowledge we do not have sufficient data to confirm this.

\section{Se- and Te-bearing pearceite-polybasite}

The contents of Te and/or Se in minerals of the pearceite-polybasite group have been reported from various types of hydrothermal ore deposits (e.g. Harris et al., 1965; Warmada et al., 2003; Jelen et al., 2007; Kovalenker et al., 2011; Voudouris et al., 2011). In Argentina, Márquez-Zavalía and Heinrich (2016) cited the presence of Te-bearing polybasite in the intermediate-sulfidation epithermal vein system of Alto de la Blenda. Se-bearing polybasite was reported by Márquez-Zavalía et al. (2008) in the epithermal gold-silver deposit of Martha mine, with values of up to $3 \mathrm{wt} \% \mathrm{Se}$.
Mugas-Lobos et al. (2011) reported a Se-bearing polybasite, with $4.18 \mathrm{wt} . \%$ of $\mathrm{Se}$, along with naumannite $\left(\mathrm{Ag}_{2} \mathrm{Se}\right)$ and Se-bearing acanthite and cervelleite from the Don Sixto deposit. Note that most of those authors reported chemical compositions that are Se-rich or Te-rich, but the two elements do not occur together. Only Warmada et al. (2003) reported one analysis of Te-bearing polybasite with $5.5 \mathrm{wt} . \%$ of Te and $3.6 \mathrm{wt} . \%$ of Se. In the case of the pearceite-polybasite minerals from Puesto La Estancia (Table 5), both elements are present. Moreover, another difference is that these analyses correspond to pearceite (or arsenopolybasite after Hall, 1967), with a high As content of $2.8-5$ wt. $\%$.

The structural role of $\mathrm{Se}$ in polybasite was studied by Bindi et al. (2007), who defined a new mineral species of the group, 'selenopolybasite'. Moreover, Bindi et al. (2013) investigated the role of Te in this group of minerals, refining the structure of a Te-rich polybasite. Those authors found that the Te-for-S substitution occurs at the same structural sites where $\mathrm{Se}$ substitutes for $\mathrm{S}$ in selenopolybasite, suggesting the possibility that 'telluropolybasite' could be found in nature. As shown in Fig. 10, there is a stronger correlation 
between Se and $\mathrm{S}$ than there is between Te and $\mathrm{S}$, suggesting that the presence of Se in the structure of polybasite is by substitution of $\mathrm{S}$ for $\mathrm{Se}$ with a nearly constant $\mathrm{Te}$ content. The $\mathrm{Cu}$ content is low $(<5$ wt. $\%)$ in accordance with the hypothesis of Bindi et al. (2007) that the $\mathrm{Cu}$ content of the pearceite-polybasite group minerals is very low if Se and/or Te are present.

\section{Gold mineralization}

Gold occurs mainly as an Au-Ag alloy or in tellurides. Invisible gold in pyrite has not been found, although it could be present in amounts below the detection limit $(250 \mathrm{ppm})$. Trace-gold contents were commonly detected in pearceite-polybasite (Table 5). The gold content in these minerals was previously mentioned by Gamarra-Urrunaga et al. (2013) in Pallancata deposit, Peru. These authors pointed to the presence of a precursor Au-rich,


FIG. 10. Variation diagrams showing the correlation between $\mathrm{S}$ (apfu) and (a) Se (apfu) and (b) Te (apfu) in the pearceite-polybasite minerals from samples of the Puesto La Estancia and Cerro Mogote prospects. Analyses are shown in Table 6. high-temperature silver sulfide. The amounts of $\mathrm{Au}$ measured in the silver sulfosalts from the Puesto La Estancia prospect and the common association of gold (Au-Ag alloy) with silver minerals such as acanthite, hessite or cervelleite (Fig. 7) indicates that gold deposition was synchronous (Fig. 8) with the formation of silver sulfides and sulfosalts, after the main base-metal ore deposition.

\section{Comparison with other epithermal deposit}

From a mineralogical point of view, the $\mathrm{Au}-\mathrm{Ag}$ epithermal mineralization of the Cerro Mogote and Puesto La Estancia prospects, in the La Carolina District, shares many similarities with the Alto de la Blenda epithermal deposit (Márquez-Zavalía and Heinrich, 2016), located in the NW of Argentina within the Farallón Negro volcanic district, and the Rosia Montana epithermal deposit (Wallier et al., 2006), in Romania.

The Alto de la Blenda epithermal mineralization is hosted by veins, with multiple events of opening and brecciation, and by polymict breccias. The mineralization consists of pyrite, sphalerite, chalcopyrite, galena and the tetrahedrite-tennantite group of minerals as the main sulfides, and of quartz and Mn-rich carbonates as gangue minerals. Adularia is absent from all vein stages (Márquez-Zavalía and Heinrich, 2016). Sphalerite crystals also appear zoned, with yellowish and $\mathrm{Fe}$-poor cores surrounded by darker and Fe-rich rims (up to 3.18 wt.\% Fe). The precious-metal paragenesis comprises $\mathrm{Au}-\mathrm{Ag}$ alloy, the polybasite-pearceite group of minerals (including the Te-bearing polybasite discussed above), acanthite and $\mathrm{Ag}-\mathrm{Cu}$ sulfides such as mackinstriyite (Márquez-Zavalía and Heinrich, 2016). However, a telluride-rich paragenesis such as that studied in the Puesto La Estancia prospect has not been found in the Alto de la Blenda deposit. In the nearby Capillitas deposit, which is also part of the Farallón Negro volcanic district, Marquez-Zavalía and Craig (2004) described a complex telluride paragenesis that includes native tellurium, krennerite, calaverite, sylvanite, petzite, hessite and stützite. According to Putz et al. (2009), the Capillitas deposit comprises high- and intermediate-sulfidation mineralization that was overprinted by supergene processes. In the case of the Alto de la Blenda deposit and according to Márquez-Zavalía and Heinrich (2016), the main sulfide assemblage together with the presence of abundant $\mathrm{Mn}$-rich carbonates, beside quartz, support the classification of the deposit as an intermediate-sulfidation $\mathrm{Au}-\mathrm{Ag}$ deposit (Hedenquist 
et al., 2000) or as a carbonate-base metal-gold vein system (Corbett and Leach, 1998).

The Rosia Montana deposit, in Romania, is a breccia-hosted epithermal system related to significant phreatomagmatic activity due to the shallow emplacement of the Montana dacite (Wallier et al., 2006). Mineralization consists of quartz, adularia, carbonates (commonly Mn-rich), with pyrite, sphalerite, galena, chalcopyrite, marcasite, arsenopyrite, alabandite and tetrahedrite as common sulfides. In this case, sphalerite is Fe-poor. Silver sulfides and sulfosalts are abundant, e.g. acanthite, the polybasite-pearceite group of minerals, proustite or argyrodite. In addition, as was mentioned previously, there is a telluride-rich paragenesis that includes hessite, sylvanite and petzite, and Tebearing argyrodite (Tămas et al., 2006). The Rosia Montana was also classified as an intermediatesulfidation epithermal deposit (Wallier et al., 2006), with an important magmatic contribution to the mineralizing fluids.

In the case of the epithermal mineralization from Puesto La Estancia and Cerro Mogote prospects, the mineral paragenesis rich in base-metals and $\mathrm{Ag}$, and the presence of $\mathrm{Mn}-\mathrm{Mg}-\mathrm{Fe}( \pm \mathrm{Ca})$ carbonates as dominant gangue minerals would lead to it being classified as a carbonate-base metal deposit (Corbett and Leach, 1998) or as an intermediatesulfidation deposit (Hedenquist et al., 2000). As noted above, the chemical conditions of the hydrothermal fluids varied during ore and gangue deposition in the mineralization of the Puesto $\mathrm{La}$ Estancia and Cerro Mogote prospects. These fluctuations may indicate the existence of different pulses of fluids (rejuvenation of the system) or variations produced by boiling, or of both, simultaneously. Fluid inclusions and stable isotope studies are needed in the La Carolina district to check this aspect.

\section{Conclusions}

The epithermal mineralization in the Cerro Mogote and Puesto La Estancia prospects, in the southeastern part of the La Carolina district (Argentina), consists of base metal and Mn-carbonate-rich mineralization, hosted in hydrothermal breccias and veins related to Mio-Pliocene maar-diatreme volcanic activity. The main conclusions of this study are:

(1) The main sulfide mineralization consists of pyrite, sphalerite and galena, with lesser amounts of chalcopyrite, marcasite, the tetrahedrite-tennantite group of minerals. Pyrite is compositionally zoned, with As-rich cores and $\mathrm{Cu}$-rich rim overgrowths.
(2) Sphalerite shows a wide range of Fe contents (up to $12.5 \mathrm{wt} . \% \mathrm{Fe}$ ) and is compositionally zoned, with alternating Fe-rich and Fe-poor bands. The sphalerite also shows variable contents of $\mathrm{Mn}, \mathrm{Cu}$, In, $\mathrm{Ga}, \mathrm{Ge}$ and $\mathrm{Ag}$. Indium was detected mainly in the Fe-poor and yellowish sphalerite. The most Inrich sphalerite (up to $5940 \mathrm{ppm}$ ) also contains elevated concentrations of $\mathrm{Cu}, \mathrm{Ag}, \mathrm{Ga}$ and $\mathrm{Ge}$, which suggests a coupled substitution mechanism resulting in monovalent cation enrichment (i.e. $\mathrm{Ag}^{+}$ and $\mathrm{Cu}^{+}$) with respective tri- and tetravalent cation enrichments $\left(\mathrm{Ga}^{3+}, \mathrm{In}^{3+}, \mathrm{Ge}^{4+}\right)$.

(3) Precious-metal mineralization mainly occurs as $\mathrm{Au}-\mathrm{Ag}$ alloy and silver sulfides and sulfosalts (acanthite, pearceite-polybasite group minerals, Ag-rich tetrahedrite). Local chemical variations produced Ge-bearing minerals (argyrodite) and/or Se-Te-bearing minerals (hessite, Se-cervelleite, TeSe-pearceite-polybasite, benleonardite, alburnite). The higher-fugacity of Te produced a $\mathrm{Au}-\mathrm{Ag} \pm \mathrm{Bi}$ $\pm \mathrm{Pb}$ telluride assemblage (hessite, sylvanite, petzite, tellurobismuthite, volynskite, altaite).

(4) The present study is another example of how epithermal deposits can be mineral sources of trace elements such as In, Ge, Te, Se and Ga which, potentially, could increase the prospectivity of these deposits.

\section{Acknowledgements}

This study was supported by the 'Proyecto de Ciencia y Técnica P-3-2-0414, of the National University of San Luis' and by the Project CGL2016-76532-R from the MINECO of Spain. The authors thank Mr Miguel Angel Fernández, EMPA technician, for his assistance. They also thank the reviewers and the Associate Editor for their suggestions which have improved the content and clarity of the paper.

\section{References}

Aceñolaza, F.G. and Toselli, A.J. (1981) Geología del Noroeste Argentino. Facultad Ciencias Naturales e Instituto Miguel Lillo, 1287. Universidad Nacional Tucumán, Argentina, Special Publication, pp. 1-212.

Afifi, A.M., Kelly, W.C. and Essene, E.J. (1988) Phase relations among tellurides, sulfides, and oxides: II. Applications to telluride-bearing ore deposits. Economic Geology, 83, 395-404.

Barazangi, M. and Isacks, B.L. (1976) Spatial distribution of earthquakes and subduction of the Nazca Plate beneath South America. Geology, 4, 686-692.

Belissont, R., Boiron, M.C., Luais, B. and Cathelineau, M. (2014) LA-ICP-MS analyses of minor and trace 
elements and bulk Ge isotopes in zoned Ge-rich sphalerites from the Noailhac-Saint-Salvy deposit (France): Insights into incorporation mechanisms and ore deposition processes. Geochimica et Cosmochimica Acta, 126, 518-540.

Bernstein, L.R. (1985) Germanium geochemistry and mineralogy. Geochimica et Cosmochimica Acta, 49, 2409-2422.

Bindi, L., Evain, M. and Menchetti, S. (2007) Selenopolybasite, $\left[(\mathrm{Ag}, \mathrm{Cu})_{6}(\mathrm{Sb}, \mathrm{As})_{2}(\mathrm{~S}, \mathrm{Se})_{7}\right]\left[\mathrm{Ag}_{9} \mathrm{Cu}\right.$ $\left.(\mathrm{S}, \mathrm{Se})_{2} \mathrm{Se}_{2}\right]$, a new member of the pearceite-polybasite group from the De Lamar Mine, Owyhee county, Idaho, USA. The Canadian Mineralogist, 45, $1525-1528$.

Bindi, L., Voudouris, P.C. and Spry, P.G. (2013) Structural role of tellurium in the mineral of the pearceitepolybasite group. Mineralogical Magazine, 77, 419-428.

Breiter, K., Gardenová, N., Kanický, V. and Vaculovič, T. (2013) Gallium and germanium geochemistry during magmatic fractionation and post-magmatic alteration in different types of granitoids: A case study from the Bohemian Massif (Czech Republic). Geologica Carpathica, 64, 171-180.

Caminos, R. (1979) Sierras pampeanas noroccidentales. Salta, Tucumán, Catamarca, La Rioja y San Juan. Pp. 225-291 in: Segundo Simposio de Geología Regional Argentina (J.C.M. Turner, editor). Academia Nacional de Ciencias, Córdoba, Argentina.

Canet, C., Camprubí, A., González-Partida, E., Linares, C., Alfonso, P., Piñeiro-Fernández, F. and ProlLedesma, R.M. (2009) Mineral assemblages of the Francisco I. Madero $\mathrm{Zn}-\mathrm{Cu}-\mathrm{Pb}-(\mathrm{Ag})$ deposit, Zacatecas, Mexico: implications for ore deposit genesis. Ore Geology Reviews, 35, 423-435.

Carrillo-Rosúa, J., Morales-Ruano, S. and Hach-Alí, P.F. (2008) Textural and chemical features of sphalerite from the Palai-Islica deposit (SE Spain): Implications for ore genesis and color. Journal of Mineralogy and Geochemistry, 185, 63-78.

Chinchilla, D., Ortega, L., Piña, R., Merinero, R., Moncada, D., Bodnar, R.J., Quesada, C., Valverde, A. and Lunar, R. (2016) The Patricia Zn-Pb-Ag epithermal ore deposit: an uncommon type of mineralization in northeastern Chile. Ore Geology Reviews, 73, 104-126.

Chouinard, A., Paquette, J. and Williams-Jones, A. (2005) Crystallographic controls on trace element incorporation in auriferous pyrite from the Pascua epithermal high-sulfidation deposit Chile-Argentina. The Canadian Mineralogist, 43, 951-963.

Cook, N.J. and Chryssoulis, S.L. (1990) Concentrations of "invisible gold" in the common sulfides. The Canadian Mineralogist, 28, 1-16.

Cook, N.J., Ciobanu, C.L., Pring, A., Skinner, W., Danyushevsky, L., Shimizu, M., Saini-Eidukat, B., and Melcher, F. (2009) Trace and minor elements in sphalerite: a LA-ICP-MS study. Geochimica et Cosmochimica Acta, 73, 4761-4791.

Cook, N.J., Sundblad, K., Valkama, M., Nygård, R., Ciobanu, C.L. and Danyushevsky, L. (2011) Indium mineralisation in A-type granites in southeastern Finland: insights into mineralogy and partitioning between coexisting minerals. Chemical Geology, 284, 62-73.

Cooke, D. and McPhail, D. (2001) Epithermal Au-Ag-Te mineralization, Acupan, Baguio district, Philippines: numerical simulations of mineral deposition. Economic Geology, 96, 109-131.

Corbett, G.J. and Leach, T.M. (1998) Southwest Pacific Rim Gold-Copper Systems: Structure, Alteration, and Mineralisation. Special Publication, 6, 234 pp. Society of Economic Geology, Golden, Colorado, USA.

Damian, G. (2003) The genesis of the base metal ore deposit from Herja. Studia UBB, Geologia, 48, 85-100.

de Brodtkorb, M.K. (2009) Precious metal tellurides and other Te-bearing minerals in different paragenesis of Argentina. A review. Revista de la Asociación Geológica Argentina, 64, 365-372.

Deditius, A.P., Utsunomiya, S., Ewing, R.C., Chryssoulis, S.L., Venter, D. and Kesler, S.E. (2009) Decoupled geochemical behaviour of $\mathrm{As}$ and $\mathrm{Cu}$ in hydrothermal systems. Geology, 37, 707-710.

Dobosi, G. and Nagy, B. (2000) Compositional variation of fahlore minerals in the hydrothermal ore deposits of Hungary. Annual Reports of the Geological Institute of Hungary, 1994-1995/II, pp. 231-273.

Franchini, M., Impiccini, A., Lentz, D., Ríos, F.J., Oleary, S., Pons, J. and Schalamuk, I.B. (2011) Porphyry to epithermal transition in the Agua Rica polymetallic deposit, Catamarca, Argentina: an integrated petrologic analysis of ore and alteration parageneses. Ore Geology Reviews, 41, 49-74.

Franchini, M., McFarlane, C., Maydagán, L., Reich, M., Lentz, D.R., Meinert, L. and Bouhier, V. (2015) Trace metals in pyrite and marcasite from the Agua Rica porphyry-high sulfidation epithermal deposit, Catamarca, Argentina: textural features and metal zoning at the porphyry to epithermal transition. Ore Geology Reviews, 66, 366-387.

Frenzel, M., Hirsch, T. and Gutzmer, J. (2016) Gallium, germanium, indium, and other trace and minor elements in sphalerite as a function of deposit typeA meta-analysis. Ore Geology Reviews, 76, 52-78.

Gallard-Esquivel, M.C. (2015) Metalogénesis y paleovolcanología del distrito aurífero La Carolina, San Luis, Argentina. PhD thesis, Universidad Nacional de San Luis, Argentina (in Spanish).

Gallard-Esquivel, M.C., Urbina, N.E., Suroga, P. and Japas, M.S. (2012) Depósitos epitermales de baja 
sulfuración ricos en sulfuros de metales base, distrito aurífero La Carolina, San Luis, Argentina. Aportes al magmatismo y metalogénesis asociada de la República Argentina. Serie de Correlación Geológica, 28, 91-102.

Gallard-Esquivel, M.C., Ibañes, O.D., Roquet, M.B, Suroga, P. and Urbina, N.E. (2015) Análisis Litofacial y mineralización epitermal asociada en el prospecto Puesto Olguín, La Carolina, San Luis. Revista de la Asociación Geológica Argentina, 72, 210-218.

Gamarra-Urrunaga, J., Castroviejo, R. and Bernhardt, H.J. (2013) Preliminary mineralogy and ore petrology of the intermediate-sulfidation Pallancata Deposit, Ayacucho, Peru. The Canadian Mineralogist, 51, 67-91.

Graedel, T.E., Gunn, G. and Tercero Espinoza, L. (2014) Metal resources, use and criticality. Pp. 1-19 in: Critical Metals Handbook (G. Gunn, editor), first edition. John Wiley \& Sons, Ltd., UK.

Grundler, P.V., Brugger, J., Etschmann, B.E., Helm, L., Liu, W.H., Spry, P.G., Tian, Y., Testemale, D. and Pring, A. (2013) Speciation of aqueous tellurium(IV) in hydrothermal solutions and vapors, and the role of oxidized tellurium species in Te transport and gold deposition. Geochimica et Cosmochimica Acta, 120, 298-325.

Gutscher, M., Spakman, W., Bijwaard, H. and Engdahl, E. (2000) Geodynamics of flat subduction: Seismicity and tomographic constraints from the Andean margin. Tectonics, 19, 814-833.

Hall, H.T. (1967) The pearceite and polybasite series. American Mineralogist, 52, 1311-1321.

Harris, D.C., Nuffield, E.W. and Frohberg, M.H. (1965) Studies of mineral sulphosalts: XIX - Selenian polybasite. The Canadian Mineralogist, 8, 172-184.

Hedenquist, J.W., Arribas, Jr, A. and González-Urien, E. (2000) Exploration for epithermal gold deposits. Reviews for Economic Geology, 13, 245-277.

Höll, R., Kling, M. and Schroll, E. (2007) Metallogenesis of germanium - A review. Ore Geology Reviews, 30, 145-180.

Japas, M.S., Urbina, N.E. and Sruoga, P. (2010) Control estructural en el emplazamiento del volcanismo y mineralizaciones neógenas, distrito Cañada Honda, San Luis. Revista de la Asociación Geológica Argentina, 67, 494-506.

Japas, M.S., Urbina, N.E., Sruoga, P. and Gallard, M.C. (2011a) La Carolina pull-apart in western Tertiary Volcanic Belt, Pampean Flat-Slab $\left(33^{\circ} \mathrm{S}\right)$, Argentina. Pp. 110 in: Abstracts of the 22nd International Lateinamerika-Kolloquium, LAK 2011, Heidelberg, Germany.

Japas, M.S., Urbina, N.E., Sruoga, P. and Gallard, M.C. (2011b) Pull apart La Carolina, Faja Volcánica Terciaria, San Luis. In: Actas XVIII Congreso Geológico Argentino, Neuquén, CD-ROM, S12.
Jelen, S., Kovalenker, V.A. and Gaber, M. (2007) Paragenetic assemblages of gold and silver minerals in ores of the Banska Stiavnica and Hodrusa deposits (The eastern Carpathians, Slovakia): Mineralogy, variation of chemical composition, and formation conditions. Pp. 178-183 in: Rol mineralogii $v$ poznanii protsessov rudoobrazovaniya (Contribution of Mineralogy to Knowledge on Ore Formation). IGEM RAN, Moscow.

Jordan, T.E. and Allmendinger, R.W. (1986) The Sierras Pampeanas of Argentina; a modern analogue of Rocky Mountain foreland deformation. American Journal of Science, 286, 737-764.

Jordan, T.E., Isacks, B.L., Alrnendinger, R.W., Brewer, J. A., Ramos, VA. and Ando, C.J. (1983) Andean tectonics related to geometry of subducted Nazca plate. Geological Society of America Bulletin, 94, 341-361.

Kovalenker, V.A., Kiseleva, G.D., Krylova, T.L. and Andreeva, O.V. (2011) Mineralogy and ore formation conditions of the Bugdaya Au-bearing W-Mo porphyry deposit, eastern Transbaikal region, Russia. Geology of Ore Deposits, 53, 93-125.

Landtwing, M., Dillenbeck, E., Leake, M. and Heinrich, C. (2002) Evolution of the brecciahosted porphyry$\mathrm{Cu}-\mathrm{Mo}-\mathrm{Au}$ deposit at Agua Rica, Argentina: Progressive unroofing of a magmatic-hydrothermal system. Economic Geology, 97, 1273-1292.

Losada-Calderón, A. and McPhail, D.C. (1996) Porphyry and high sulphidation epithermal mineralization in the Nevados de Famatina Mining district, Argentina. New discoveries, mineralization styles and metallogeny. Special Publication, 5, pp. 91-118, Society of Economic Geologists, Golden, Colorado, USA.

Makovicky, E. and Karup-Møller, S. (1994) Exploratory studies on substitution of minor elements in synthetic tetrahedrite. I. Substitution by Fe, Zn, Co, Ni, Mn, Cr, $\mathrm{V}$ and $\mathrm{Pb}$. Unit cell parameter changes on substitution and the structural role of $\mathrm{Cu}^{2+}$. Neues Jahrbuch für Mineralogie-Abhandlungen, 167, 89-123.

Manske, S., Ullrich, T., Reynolds, J. and O'Connor, G.V. (2004) Vein sets and hydrothermal alteration in the Cetate-Carnic Area, Rosia Montana district, Romania. Romanian Journal of Mineral Deposits, 81, 122-125.

Márquez-Zavalía, M.F. (1999) El yacimiento Capillitas, provincia de Catamarca. Pp. 1643-1652 in: Recursos Minerales de la República Argentina (E.O. Zappettini, editor). SEGEMAR, Buenos Aires.

Marquez Zavalía, M.F. and Craig, J.R. (2004) Tellurium and precious-metal ore minerals at Mina Capillitas, Northwestern Argentina. Neues Jahrbuch für Mineralogie, Monatshefte, 4, 176-192.

Márquez-Zavalía, M.F. and Galliski, M.A. (1994) Mineralogía y paragénesis de "La Estancia", un depósito epitermal de la Sierra de san Luis. Revista de la Asociación Geológica Argentina, 49, 39-47. 
Marquez-Zavalía, M.F. and Galliski, M.A. (2004) Freisbelenita, diaforita, pirargirita y acantita de la mina La Carolina, Departamento Pringles, provincia de San Luis. Pp. 77-82 in: Actas $7^{\circ}$ Congreso de Mineralogía y Metalogenia, 2004, Río Cuarto.

Márquez-Zavalía, M.F. and Heinrich, C.A. (2016) Fluid evolution in a volcanic-hosted epithermal carbonatebase metal-gold vein system: Alto de la Blenda, Farallón Negro, Argentina. Mineralium Deposita, 51, 873-902.

Márquez-Zavalía, M.F., Bindi, L., Márquez M. and Menchetti, S. (2008) Se-bearing polybasite-Tac from the Martha mine, Macizo del Deseado, Santa Cruz, Argentina. Mineralogy and Petrology, 94, 145-150.

Márquez-Zavalía, M.F., Galliski, M.A., Milan Drábek, H. and Bernhardt, J. (2014) Ishiharaite, (Cu, Ga,Fe,In,Zn) $\mathrm{S}$, a new mineral from the Capillitas mine, Northwestern Argentina. The Canadian Mineralogist, 52, 969-980.

Moëlo, Y., Makovicky, E., Mozgova, N.N., Jambor, J.L., Cook, N., Pring, A., Para, W., Nickel, E.H., Graeser, S., Karup-Møller, S. et al. (2008) Sulfosalt systematics: a review. Report of the sulfosalt subcommittee of the IMA Commission on Ore Mineralogy. European Journal of Mineralogy, 20, 7-46.

Morosini, A.F., Ortiz Suarez, A.E., Otamendi, J.E., Pagano D.S. and Ramos, G.A. (2017) La Escalerilla pluton, San Luis Argentina: The orogenic and postorogenic magmatic evolution of the famatinian cycle at Sierras de San Luis. Journal of South American Earth Sciences, 73, 100-118.

Moura, M.A., Botelho, N.F. and Carvalho de Medonca, F. (2007) The indium-rich sulfides and rare arsenates of the Sn-In-mineralized Mangabeiora A-type granite, Central Brazil. The Canadian Mineralogist, 45, 485-496.

Mugas-Lobos, A.C., Márquez-Zavalía, M.F. and Galliski, M.A. (2011) Selenium and precious metal-bearing minerals at Don Sixto mining project, Mendoza, Argentina. Pp. 26-29 in: 11th SGA Biennial Meeting "Let's Talk Ore Deposits", Antofagasta, Chile.

Ortiz Suárez, A., Prozzi, C. and Llambías, E. (1992) Geología de la parte Sur de la Sierra de San Luis y granitoides asociados, Argentina. Revista Estudios Geológicos, 48, 269-277.

Paar, W.H. and Putz, H. (2005) Germanium associated with epithermal mineralization: examples from Bolivia and Argentina. Pp. 48-51 in: Mineral Deposit Research: Meeting the Global Challenge, 3 (C.S. Zhao and B.J. Guo, editors). China Land Publishing House, Beijing.

Paar, W.H., Roberts, A.C., Berlepsch, P., Armbruster, T., Topa, D. and Zagler, G. (2004a) Putzite, $\left(\mathrm{Cu}_{4.7} \mathrm{Ag}_{3.3}\right)$ $\Sigma 8 \mathrm{GeS}_{6}$, a new mineral species from Capillitas, Catamarca, Argentina: description and mineral structure. The Canadian Mineralogist, 42, 1757-1769.
Paar, W., Topa, D., Sureda, R., Stumpfl, E. and Mühlhaus, H. (2004b) Merenskyite, PdTe2, en las menas de Se$\mathrm{Cu}$ y Ag de la mina Las Asperezas, distrito minero Sierra de Umango, provincia de La Rioja, Argentina. Pp. 113-118 in: $7^{\circ}$ Congreso de Mineralogía y Metalogenia, Actas, Buenos Aires.

Paradis, S. (2015) Indium, germanium and gallium in volcanic- and sediment-hosted base-metal sulphide deposits. Pp. 23-29 in: Symposium on Strategic and Critical Materials Proceedings, November 13-14, 2015, Victoria, British Columbia (G.J. Simandl and M. Neetz, editors). British Columbia Ministry of Energy and Mines, British Columbia Geological Survey Paper 2015-3.

Proffett, J.M. (2004) Geology of the Bajo de la Alumbrera porphyry copper-gold deposit, Argentina. Economic Geology, 98, 1535-1574.

Prozzi, C. (1990) Consideraciones acerca del basamento de San Luis. Pp. 452-455 in: Actas $11^{\circ}$ Congreso Geológico Argentino, San Juan, 1.

Prozzi, C. and Ramos, G. (1988) La formación San Luis. Abstracts Primeras Jornadas de Trabajo de Sierras Pampeanas, San Luis, 1.

Putz, H., Paar, W., Topa, D., Makovicky, E. and Roberts, A. (2006) Catamarcaite, $\mathrm{Cu}_{6} \mathrm{GeWS}_{8}$, a new germanium sulfide mineral species from Capillitas, Catamarca, Argentina: description, paragenesis and crystal structure. The Canadian Mineralogist, 44, 1481-1497.

Putz, H., Paar, W.H. and Topa, D. (2009) A contribution to the knowledge of the mineralization at mina Capillitas, Catamarca. Revista de la Asociación Geológica Argentina, 64(33), 514-524.

Ramos, V.A., Cristallini, E.O. and Pérez, D.J. (2002) The Pampean flat-slab of the Central Andes. Journal of South American Earth Sciences, 15, 59-78.

Reed, S.J.B. and Buckley, A. (1996) Virtual WDS. Pp. 479-483 in: Microbeam and Nanobeam Analysis (D. Benoit et al., editors). Mikrochimica Acta Supplement, Springer, Vienna.

Sato, A.M., Gonzáles, P. and Llambías, E. (2003) Evolución del Orógeno Famatiniano en la Sierra de San Luis: magmatismo de arco, deformación y metamorfismo de bajo a alto grado. Revista de la Asociación Geológica Argentina, 58, 487-504.

Sahlström, F., Arribas, A., Dirks, P., Corral, I and Chang, Z. (2017) Mineralogical distribution of germanium, gallium and indium at the Mt Carlton high-sulfidation epithermal deposit, NE Australia, and comparison with similar deposits worldwide. Minerals, 7, 213-241.

Savage K.S., Tingle, T.N., O’Day, P.A., Waychunas, G.A. and Bird, D.K. (2000) Arsenic speciation in pyrite and secondary weathering phases, Mother Lode gold district, Tuolumne County, California. Applied Geochemistry, 15, 1219-1244.

Schalamuk, I.B. and Logan, A.V. (1994) Polymetallic AgTe bearing paragenesis of the Cerro Negro district, 


\section{ENRICHMENT IN CRITICAL METALS (In-Ge) AND Te-Se IN EPITHERMAL DEPOSITS}

Famatina range, La Rioja, Argentina. The Canadian Mineralogist, 32, 657-670.

Simon, G., Kesler, S.E. and Essene, E.J. (1997) Phase relations among selenides, sulfides, tellurides, and oxides: II. Applications to selenide-bearing ore deposits. Economic Geology, 92, 468-484.

Simon, G., Huang, H., Penner-Hahn, J.E., Kesler, S.E. and Kao, L.-S. (1999) Oxidation state of gold and arsenic in gold-bearing arsenian pyrite. American Mineralogist, 84, 1071-1079.

Sims, J.P., Stuart-Smith, P.G., Lyons, P. and Skirrow, R.G. (1997) Informe geológico y metalogénico de las Sierras de San Luis and Comechingones, provincias de San Luis y Córdoba. Servicio Geológico Minero Argentino Anales, 28, 1-148.

Sruoga, P., Urbina, N.E. and Malvicini, L. (1996) El volcanismo Terciario y los depósitos hidrotermales $(\mathrm{Au}, \mathrm{Cu})$ asociados en La Carolina y Diente Verde, San Luis, Argentina. Actas, $13^{\circ}$ Congreso Geológico Argentino, Buenos Aires, 3, 89-100.

Tămaş, C.G., Bailly, L., Ghergari, L., O’Connor, G. and Minuţ, A. (2006) New occurrence of tellurides and argyrodite at Roşia Montana, Apuseni Mountains, Romania and their metallogenetic significance. The Canadian Mineralogist, 44, 689-705.

Urbina, N.E. (2005a) La actividad hidrotermal vinculada al volcanismo Terciario de San Luis, Argentina. Instituto Superior de Correlación Geológica, Serie Correlación Geológica, 19, 123-132.

Urbina, N.E. (2005b) Cenozoic magmatism and mineralization in the Sierras Pampeanas of San Luis, Argentina. Pp. 787-796 in: Geological Society of
Nevada Symposium 2005, Window to the World, Proceedings 2 (H.N. Rhoden et al., editors). Reno, Nevada, USA.

Urbina, N.E. and Sruoga, P. (2009) La faja metalogénicatica de San Luis, Sierras Pampeanas: mineralización y geocronología en el contexto metalogenético regional. Revista de la Asociación Geológica Argentina, 64, 635-645.

Urbina, N.E, Sruoga, P. and Malvicini, L. (1997) Late Tertiary gold-bearing volcanic belt in the Sierras Pampeanas of San Luis, Argentina. International Geology Review, 39, 287-306.

Voudouris, P.C., Spry, P.G., Sakellaris, G.A. and Mavrogonatos, C. (2011) A cervelleite-like mineral and other Ag-Cu-Te-S minerals $[\mathrm{Ag} 2 \mathrm{CuTeS}$ and (Ag, $\mathrm{Cu}$ )2 TeS] in gold-bearing veins in metamorphic rocks of the Cycladic Blueschist Unit, Kallianou, Evia Island, Greece. Mineralogy and Petrology, 101, 169-183.

Wallier, S., Kouzmanov, R.R.K., Pettke, T., Heinrich, C.A., Leary, S., Connor, G.O, Tamas, C.G. and Vennemann, T.U. (2006) Magmatic fluids in the breccia-hosted epithermal $\mathrm{Au}-\mathrm{Ag}$ deposit of Rosia Montana, Romania. Economic Geology, 101, 923-954.

Warmada, I.W., Lehmann, B. and Simandjuntak, M. (2003) Polymetallic sulfides and sulfosalts of the Pongkor epithermal gold-silver deposit, west Java, Indonesia. The Canadian Mineralogist, 41, 185-200.

Ye, L., Cook, N.J., Ciobanu, C.L., Yuping, L., Qian, Z., Tiegeng, L., Wei, G., Yulon, Y. and Danyushevskiy, L. (2011) Trace and minor elements in sphalerite from base metal deposits in South China: A LA-ICPMS study. Ore Geology Reviews, 39, 188-217. 